\title{
IGLESIA Y PRENSA ESPAÑOLA FRENTE A LA UNIFICACIÓN DE ITALIA. SAGASTA Y EL DEBATE SOBRE EL PODER TEMPORAL DEL PAPA*
}

\author{
Sergio Cañas Díez \\ Universidad de La Rioja
}

RESUMEN: La cuestión de la unificación de Italia, iniciada al calor de las revoluciones europeas de 1848, suscita un gran interés por cuanto transformó las bases geopolíticas de la Europa occidental y mediterránea nacidas en el Congreso de Viena de 1815, y porque este proceso unionista fue el germen así como la continuación y expansión de distintos enfrentamientos parlamentarios, periodísticos y sociopolíticos de la España decimonónica. Concretamente en este trabajo nos centraremos en la polémica que mantuvieron ultracatólicos, moderados y progresistas por la cuestión italiana, donde destaca el debate mantenido entre Práxedes Mateo-Sagasta y el cardenal arzobispo de Santiago sobre el poder temporal del pontificado, así como en las informaciones que Ilegaban a la opinión pública a través de la prensa afín a esas mismas posturas ideológicas.

Palabras clave: Unificación de Italia, prensa, Iglesia, Sagasta, opinión pública.

ABSTRACT: The question of the unification of Italy, initiated during the European revolutions of 1848, consistently arouses great interest as it transformed the geopolitical bases of the western and Mediterranean Europe declared in The Congress of Vienna of 1815, and because of this unionist process was the germ as well as the continuation and expansion of different parliamentary, journalistic and socio-political clashes in nineteenth-century Spain. Concretely in this work we

* Este trabajo se enmarca dentro del proyecto "Retórica e Historia. Los discursos parlamentario de Salustiano de Olózaga (1936-1843)" subvencionado por el Ministerio de Ciencia e Innovación (Ref. FFI2008-04419). Constatamos el agradecimiento a dicha Institución. 
will centre on the polemic that ultracatholics, moderates and progressives kept about the Italian unification matter, where we emphasizes the debate supported between Práxedes Mateo-Sagasta and the cardinal archbishop of Santiago on the temporary power of the pontificate, as well as in the information that informed public opinion across the related press to the same ideological views.

Keywords: Unification of Italy, press, the Church, Sagasta, public opinion.

\section{Introducción}

En el presente año de 2011 se conmemoran los ciento cincuenta años, el sesquicentenario, que nos separan de 1861. Una fecha con la que se rememora el nacimiento del reino y de la nación de Italia. Así, no es extraño, que tal efeméride despierte el interés historiográfico por profundizar aún más en el estudio de este tema'.

Para la investigación del siglo XIX, la cuestión de la unificación de Italia suscita un gran interés por cuanto transformó las bases geopolíticas de la Europa occidental y mediterránea, y porque este proceso unionista fue el germen así como la continuación y expansión de distintos enfrentamientos parlamentarios, periodísticos y sociopolíticos en España ${ }^{2}$. Concretamente en este trabajo nos

1. Por ejemplo contamos con los recientes casos del Convegno I territorio della Nazione, celebrado durante los días 24 y 25 de marzo de 2011 en la Universidtá degli Studi di Salerno, y con la Mostra documentaria Un popolo uno stato. Conquiste e problematiche dell'Unizicazione Italiana viste da una provincia meridionale, organizada por el Ministerio per i Beni e le Actività Culturali y por el Archivo di Stato di Salerno, desde marzo del mismo año, y que se localiza en el Archivo di Stato di Salerno. Aprovecho para agradecer al archivero don Franco Manzione, al profesor don Carmine Pinto y a la directora de dicho archivo, doña Eugenia Granito, que tuvieran a bien invitarme a participar en ambos eventos, así como doy las gracias al archivero de la catedral de Calahorra don Ángel Ortega, a la archivera del Archivo Histórico de Loyola, doña Olatz Berasategui, al doctor y profesor don José Miguel Delgado Idarreta de la Universidad de La Rioja, y a los traductores don David Ijalba y doña Ana Téllez, por su inestimable ayuda profesional en la resolución de dudas archivísticas, historiográficas y lingüísticas.

2. Las relaciones y conexiones entre la historia de Italia y España no sólo son evidentes en esta cuestión, quizás una de las más directas pero desde luego no la única, pues otros autores, tanto españoles como italianos, se han encargado de demostrar paralelismos y analogías inmersas en la historia de ambos países en obras de carácter más amplio, de la misma forma que en artículos más específicos. Vide Suárez Cortina, M. y Casmirri, S. (Editores), La Europa del Sur en la época liberal. España, Italia y Portugal: una perspectiva comparada, Santander-Cassino, 1998; Suárez Cortina, M. (Editor), La crisis del Estado liberal en la Europa del Sur, Santander, Universidad de Cantabria/Sociedad Menéndez Pelayo, 2000; García Sanz, F. España e Italia en la Europa contemporánea: desde finales del siglo XIX a las dictaduras, Madrid, Consejo Superior de Investigaciones Científicas, 2002. Para conocer "la versión italiana", Vide Mugnaini, M., Italia e Spagna nell'età contemporanea. Cultura, politica e diplomazia (1814-1870), Alessandria, Edizioni dell’Orso, 1994. En cuanto a obras más específicas, contamos con el artículo de Casmirri, S., "Sagasta y su actividad de gobierno en la prensa italiana", en Delgado Idarreta, J.M. y Ollero 
centraremos en la polémica que mantuvieron ultracatólicos y progresistas, representados respectivamente en el cardenal arzobispo de Santiago, Miguel García Cuesta, y el periodista y político riojano Práxedes Mateo Sagasta, por la polémica en torno al poder temporal del papado, es decir, de la Iglesia católica occidental que a la sazón era la que se encontraba, de la misma forma que sucede en la actualidad, bajo su control. Aunque como veremos a continuación, éste no fue el único motivo de disputa ni de tensión nacional, ni tampoco ellos fueron los únicos implicados, sí que merecen que les prestemos nuestra atención a tenor de la ingente cantidad de artículos y cartas que se cruzaron en donde el debate político, histórico y filosófico aparecían entremezclados en un todo y presentados a través de argumentos intelectuales.

El movimiento unitario italiano no pasó inadvertido para ninguna fuerza política y social española; todas ellas tomaron posición ante esta cuestión. Unos lo hicieron a favor y otros en contra, y es respecto a esta última postura, más ambigua y menos cohesionada, sobre la que voy a encauzar mi propuesta en una primera parte. Posteriormente, nos centraremos en los hechos y en los discursos que se dieron en los momentos más relevantes del proceso unificador italiano, por parte de la Iglesia española, para en un segundo estadio pasar a ver cómo reaccionaron los sectores sociales más progresistas en base a sus propias coordenadas políticas y a la argumentación ultra y neocatólica, teniendo al moderantismo de la Unión Liberal como telón de fondo gubernamental desde 1856 hasta 1868.

La difícil y a menudo encontrada dialéctica entre catolicismo y liberalismo durante el siglo XIX, tiene en la cuestión italiana uno de sus puntos álgidos. Sobretodo, tras los movimientos revolucionarios de 1848 . No resulta, pues, extraño que un pontífice como Pío IX, crecido y educado en el seno de una familia liberal, previniese y adoctrinase al total del orbe católico "contra los adoradores de la razón humana" ${ }^{3}$, indicando claramente cual debía ser la postura política-ideológica de la iglesia, dentro del convulso giro ideológico que había dado a su papado tras $1848^{4}$. Una fecha que por otra parte, marca el inicio del proceso liberal-unificador de Italia.

Vallés, J.L., (editores), El liberalismo europeo en la época de Sagasta, Fundación Práxedes Mateo Sagasta, Madrid, 2009, pp. 239-274.

3. Pastoral del obispo de Vitoria sobre la Encíclica "Quanta Cura" y "Syllabus" de Pío IX. Boletín Eclesiástico del Obispado de Vitoria (BEOV), 20 de mayo de 1865. Vide Revista Católica, Historia Contemporánea de los padecimientos y triunfos de la Iglesia de Jesucristo, t. 25, Barcelona, 1855.

4. Pío IX fue Ilamado inicialmente "el papa liberal" si bien terminó luchando denodadamente contra el liberalismo tras sus experiencias con el liberalismo más radical. Según Ludwig Hertling en Historia de la Iglesia, Barcelona, Herder, 1961, pp. 441-442, fueron muchas las esperanzas puestas en la elección de Juan María Mastai Ferretti como Pío IX en 1846. Sus celebradas amnistías políticas y sus reformas de talante democrático le hicieron simpático a los ojos 
No se trataba únicamente de un asunto de política internacional o de un enfrentamiento entre potencias rivales que luchaban por mantener y expandir sus intereses económicos y políticos. Lo que estaba encima de la mesa era la continuación, o no, del orden geopolítico europeo surgido en el Congreso de Viena en 1815, pese a que hubiese salido algo malparado tras las oleadas revolucionarias de 1848. Y es sobre esta cuestión, sobre la que van a incidir otros factores de índole religiosa y dinástica, que podían surgir, como de hecho surgieron, al hacerse imprescindibles para materializar la unidad de Italia. Dejando a un lado la cuestión dinástica, pues no es el tema de mi investigación, será la problemática de los Estados pontificios el hecho que complicaría enormemente la situación, ya que a los ojos de muchos estadistas y hombres del clero suponía la desaparición del secular poder temporal de la Iglesia.

\section{Situación de la Iglesia española en el siglo XIX}

El clero español, recibió valoraciones contradictorias de sus contemporáneos: las críticas liberales encaminadas a denunciar su excesivo número y su limitada preparación cultural, chocan con las apologías que se hacían de ese mismo clero por sectores antiguorregimentales y conservadores de la sociedad española. La razón es clara, unos miraban desde una óptica política-liberal mientras que los adversarios lo hacían desde un prisma puramente teológico ${ }^{5}$. De esta forma, la situación se hacía irresoluble por vías meramente diplomáticas, y por desgracia, faltó la concordia entre un clero inmovilista y anclado en el pasado, y unos liberales revolucionarios que no eran capaces de penetrar en un pueblo tradicional y eminentemente católico.

de muchos unionistas que relacionaban su pontificado con la causa italiana, pero cuando en la primavera de 1848 se opuso tajantemente en la guerra de liberación de Cerdeña contra Austria, esos mismos sectores desencadenaron una revolución en Roma por lo que Pío IX tuvo que exiliarse en Gaeta. Tras la derrota piamontesa y la conquista francesa de Roma, poniendo fin a la experiencia de la republica de los "manzzinianos", el papa regresó a su capital: los patriotas italianos comprendieron que la unidad nacional no podía hacerse con el papa, sino contra él. Del mismo modo, cuando las tropas italianas tomasen Roma en 1870 el papa se recluiría en el Vaticano negándose a entrar en negociaciones. Vide Ferrer Benimeli, José A. "Masonería, Iglesia, Liberalismo" en Delgado Idarreta, J.M. y Ollero Vallés, J.L., (editores), El liberalismo europeo en la época de Sagasta, Fundación Práxedes Mateo Sagasta, Madrid, 2009, pp. 116-137.

5. Para conocer de primera mano las críticas Vide Gallardo, B.E., Diccionario crítico-burlesCo, Cádiz, 1812; Miñano, S., Lamentos políticos de un pobrecito holgazán, Reed, Madrid, 1968; Anónimo, Abusos introducidos en la disciplina de la Iglesia, Madrid, 1813 y Cartas del compadre del holgazán, Madrid, 1822; Blanco White, J.M., Cartas de España, Reed, Madrid, 1972. Por otro lado, encontramos numerosas apologías, especialmente durante el Trienio Constitucional de Riego. Vide Colección eclesiástica española, Madrid, 1823-1824, como también durante la monarquía isabelina, como en Melguizo, A., Honra y gloria del clero español, Madrid, 1843. 
En los primeros años del siglo XIX, hay en España una población clerical estimada en más de 111.000 personas frente a una población total de algo más de 10.000.000 de habitantes. La proporción es altísima: había un religioso por cada 92 fieles. Todo ello sin contabilizar a otras personas vinculadas a la Iglesia como sacristanes, donados, monjas o ermitaños, cuyo número rondaba los $25.000^{6}$.

La imagen que tenemos de ese clero, es la de personas que perciben rentas por su estamento y que es reacio a colaborar en todo lo que se saliese de sus obligaciones religiosas o de culto. Un culto que fundamentalmente es externo y pomposo desde el Concilio de Trento, y al que acuden los poderes públicos, las autoridades civiles y la masa popular.

Tampoco faltaron ejemplos de actitudes intelectuales y caritativas entre los miembros del clero, pero su número era muy escaso para una población religiosa tan abundante. Por ejemplo, el episcopado español siempre denotó una integridad moral, una formación intelectual y un conocimiento teológico que los destacaba sobre el común de los religiosos de la época.

En lo relativo al bajo clero, contamos con distintos informes que hacían de ellos sus superiores para saber más sobre él: en un testimonio que el nuncio Tiberi hace a Roma, se elogiaba la actitud de los religiosos españoles por su excelente espíritu, los obispos se representaban como dignidades muy respetables, pero, se afirmaba que el bajo clero y los curas rurales estaban desprestigiados por su ignorancia y eran motivo de escándalos por su disipada conducta y embriaguez pública .

Pero estas situaciones no escapaban del control y de la reprimenda de los obispos. Así, el obispo de Calahorra-La Calzada, don Anastasio Puyol Poveda ${ }^{8}$, encargado de la amplísima diócesis que ocupaba territorios de las actuales provincias de La Rioja, Vizcaya, Guipúzcoa, Álava, Navarra, Burgos y Soria, conminaba al clero de su diócesis a finalizar feas conductas personales nada más llegar a su palacio de Calahorra, pues había podido comprobar como sus sacerdotes estaban "públicamente notados e infamados de incontinencia", y como los había que vivían amancebados con sus amas o criadas. Había otros que eran tratantes en ferias y mercados, e incluso eran reconocidos entre la población como jugadores profesionales. Además de una amplia lista de con-

6. Censo de la población de España en el año 1797 executado (sic) de orden del rey en el de 1801. N. XLIV. Estos y otros datos pueden consultarse en Sáez Marín, J., Datos sobre la Iglesia española contemporánea, 1768-1868, Madrid, 1975; De Jonnes, M., Estadística de España, Barcelona, 1835.

7. Despacho de Tiberi a Della Somaglia, Madrid, 24 de octubre de 1829, en Cárcel, V., Correspondencia diplomática del nuncio Tiberi (1827-1834), Pamplona, 1976, pp. 59.

8. Para saber más sobre este personaje, se puede consultar la siguiente obra: E. Sáinz. Sedes episcopales de La Rioja, Obispado de Calahorra y la Calzada, Logroño, 1994, Tomo IV. 
ductas católicamente inmorales y socialmente seglares, relativas a conductas, modales, lenguaje y diversiones, también se llega a denunciar la práctica de ciertos sacerdotes que hacían misas muy breves para "captarse la benevolencia del pueblo rudo". Aunque el mismo obispo reconoce que no era una tendencia general del clero de su diócesis, al ser tan amplia su administración eran muchos los lugares y sacerdotes a su cargo, sí que reconoce que lo que está muy extendida es la ociosidad cuando no había oficio religioso que hacer ${ }^{9}$.

Es este clero el que sufre las reformas religiosas que el inicio del liberalismo en España trajo consigo en la década de 1833-1843, en forma de desamortización y exclaustración. Esta crisis provocó fundamentalmente dos tipos de reacciones: por un lado encontramos a nostálgicos del pasado que aspiraban a volver a la situación pre-liberal, como había sucedido de hecho en las dos primeras experiencia liberales de España, a saber; de 1808 hasta 1814, los años de la Guerra de la Independencia, y de 1820 hasta 1823, en el Trienio Constitucional. Por otra parte, hayamos a personas con mayor perspectiva de futuro, que pese a que no apoyen las nuevas medidas revolucionarias, se esforzaban por encontrar nuevas soluciones para la acción pastoral de la Iglesia.

El concordato de 1851 trazó un nuevo rumbo para la reorganización del clero español. Una reorganización que se había visto precedida por una serie de medidas dirigidas a reducir el número de religiosos por distintas vías políticas y económicas. Como compensación a las reformas religiosas, el clero recibiría una pensión estatal modesta, pero más segura y equilibrada que la antigua. Al mismo tiempo, el Estado se aseguraba el control numérico y político del clero, control este último que tuvo unas consecuencias más relativas, como demostraron por ejemplo los párrocos carlistas.

En lo referente a la elevación del nivel espiritual e intelectual del clero, encontramos que, en conjunto, el nuevo clero es más responsable y está mejor preparado que el antiguo: hay mejores medios de educación, se regulan conferencias, retiros y ejercicios espirituales, se escriben revistas y boletines especializados para los eclesiásticos ${ }^{10}$, y en suma, se ponen medios prácticos para el aumento de los conocimientos culturales, científicos y teológicos del sacerdocio. Sin embargo, el principal problema seguía siendo que la orientación de este nuevo clero era el mantenimiento y cultivo de los católicos practicantes, y no

9. Archivo Histórico de Loyola. Historia Eclesiástica. Caja 6, nº 1. Legajo 1. Anastasio Puyol Poveda, Obispo de Calahorra y la Calzada. A todo el clero de nuestra diócesis. Calahorra, 3 de marzo de 1816.

10. Por ejemplo en el territorio de la actual Comunidad Autónoma de La Rioja, encontramos a partir de 1857 un buen ejemplo de este tipo de prensa. Vide Viguera Ruiz, R., EL Escudo Católico. Periódico religioso-moral, científico-literario, Gobierno de La Rioja, Instituto de Estudios Riojanos y Ayuntamiento de Logroño, Logroño, 2010. Edición facsímil. También en Calahorra desde 1853 se comenzaba a editar el Boletín Eclesiástico de la diócesis de Calahorra, (BEDC). 
tanto el diálogo con las tendencias seculares de la política y de la cultura española. Esto provocó a corto, medio y largo plazo, que la Iglesia española, sobretodo la jerarquía, se alejara de antiguas tendencias regalistas y jansenistas, marcando aún más el ostracismo cultural católico español: la vieja teología se separaba más de la ciencia moderna ${ }^{11}$.

Resulta convincente la tesis de Biagini, cuando afirma que: "entre las fuerzas que trabajaban a favor del apoyo político al liberalismo en el siglo XIX en Europa occidental, la religión fue, tal vez, la principal y la que condicionó la misma naturaleza del liberalismo en su diversas manifestaciones nacionales. En la Europa suroccidental, el cristianismo jugo un papel opuesto"12. Por el motivo del primer tema que estamos tratando, la iglesia y la prensa española frente a la unificación de Italia, no nos interesa tanto la primera afirmación como la segunda. Si nos centramos en la Europa mediterránea y católica, Italia y España fundamentalmente, no nos resulta extraño que los liberales no tuvieran, en ocasiones, más elección que ir contra una Iglesia que estaba inflexiblemente opuesta a todo cambio estructural en las sociedades y en las naciones ${ }^{13}$.

\section{La posición de la Iglesia española ante la Unidad de Italia}

El nuevo clero isabelino, que será el que tuvo que lidiar con la compleja situación de la unidad de Italia, demostraría una férrea unidad de criterios en torno a los distintos episcopados. Alejándose de tendencias religiosas más abiertas y dialogantes con el liberalismo, serán las tendencias ultramontanas y ultracatólicas las que se impongan, así como la veneración por la persona de Pío IX. Si bien, hubo raras pero honrosas excepciones, será el ideario católico conservador el que se imponga ${ }^{14}$.

Es aquí donde surge la paradoja, pues si bien el clero alardeaba y llevaba por bandera el hecho de no injerir en la política, y criticaba a liberales, socia-

11. Vide Jiménez Duque, B., La espiritualidad española en el siglo XIX, Madrid, 1974, pp. 72-80, y Cuenca, J.M., "Notas para el estudio de los seminarios españoles en el pontificado de Pío IX" en Saitabi, no 23, 1976, pp. 51-87.

12. Vide Biagini, E.F., "Liberalismo y religión en el siglo XIX en Europa", en Delgado Idarreta, J.M. y Ollero Vallés, J.L., (editores), El liberalismo europeo en la época de Sagasta, Fundación Práxedes Mateo Sagasta, Madrid, 2009, pp. 87-98.

13. El enfrentamiento no era inevitable, puesto que de haberlo sido se hubieran sucedido en toda la Europa y la América católica. Otra de las razones que se puede esgrimir junto al estudio de Biagini, es que aún en en la Europa católica hubo ejemplos de distintos católicos liberales prominentes, como el político e intelectual francés Alphonse Lamartine, el nacionalista irlandés Daniel O’Connell o el novelista italiano Conde Alessandro Manzoni, por citar algunos personajes de la vida política, artística y cultural del siglo XIX.

14. Clérigos citados en la obra de Menéndez Pelayo, M., Historia de los heterodoxos españoles, Consejo Superior de Investigaciones Científicas, Madrid, 1992, lib. 7, caps. 2 y 3. 
listas, demócratas y republicanos, por querer inmiscuirse en asuntos eclesiásticos, lo cierto es que el clero español se vio arrastrado por el Papa y por los obispos al mantenimiento y defensa de posiciones religiosas que encerraban en su seno posiciones políticas conservadoras.

\section{1. ¿Expedición o cruzada? España y los sucesos de 1849-1859}

El movimiento de unidad italiano puso de manifiesto la crisis definitiva del sistema de orden que imperaba en Europa desde el Congreso de Viena de 1815, si bien éste ya había sido herido de gravedad tras las oleadas revolucionarias de 1848. Este proceso de unidad, pero también de cambio, se complicaba todavía más por la cuestión del poder temporal del Papado y por la actitud de Pío IX de condena del movimiento por la unidad de Italia y de los principios que la sustentaban.

Ante este panorama tan fluctuante, tan poco estable, no extraña demasiado el que una nación históricamente católica como España, su reina Isabel de la dinastía de los Borbones, sus gobiernos y sus gentes, apareciesen en conjunto contrarios a la unidad, favorables a los soberanos expulsados de sus Estados, y entre los más activos defensores de la "necesaria" existencia del poder temporal del Papa. Un poder mantenido a capa y espada, y que costó sangre, sudor y lágrimas levantar y mantener desde los primeros compases de la Alta Edad Media.

La expedición española a Roma en 1849, respondiendo a una petición de ayuda de Pío IX a todas las potencias católicas, es el paradigma de la España católica, imperial y quijotesca de la que progresivamente sólo iría quedando el recuerdo a finales del siglo XIX. La República francesa de Luis Napoleón, así como Austria y Nápoles también se adhirieron a esa llamada de socorro pontificia, pero centrándonos en la actuación española, y considerando su retraso en llegar al teatro de operaciones, su poca importancia numérica y la premura francesa por Ilevar la iniciativa católica europea, podemos explicar porque España no cumplió con las expectativas diplomáticas, nacionales y exteriores, que se habían previsto ${ }^{15}$.

En resumen, la monarquía española no podía, como hizo, mandar más que 8.000 hombres, lo cual ante los ojos del Papa y del resto de naciones europeas dejaba claro que la posición real y material de España para la causa de Pío IX, iba a ser sobretodo moral y caballeresca ${ }^{16}$.

15. Jiménez Núñez, F., Los Gobiernos de Isabel Il y la cuestión de Italia. Ministerio de Asuntos Exteriores, Madrid, 1988. Algunos autores defienden la idea de que "otra habría sido la suerte que habría librado al ejército español si hubiese llegado dos meses antes", pues por todos los factores citados, se tuvo que conformar con operaciones de poca importancia y posiciones estratégicas menores. Vide Becker, J., Historia de las relaciones exteriores de España durante el siglo XIX: apuntes para una historia diplomática. Analecta Ediciones y Libros, Pamplona, 2006.

16. Moscati, R., Austria, Napoli e gli stati conservatori italiani (1849-52). Desde Roma se había previsto que España debía mandar unos 30.000 hombres, para tomar la ciudad, un hecho 
Por lo que respecta a la Iglesia española de esa década, el apoyo hacia la causa del Papa, identificada en todo momento con la causa del catolicismo, es más que evidente si analizamos documentación eclesiástica de la época. Así, el 4 de diciembre de 1848 por una real orden se ordenaba que: “(...) en todas las Iglesias de los dominios de España se hagan rogativas públicas durante tres días consecutivos, con asistencia de todo el clero, autoridades y corporaciones (...) a fin de implorar los auxilios del Altísimo para que tengan feliz y pronto término las necesidades de la Iglesia Católica y las tribulaciones de su pastor universal"17.

Así, una vez que Pío IX pudo volver a entrar en Roma, tras haber derrotado a sus adversarios, la noticia fue recibida y tratada en España como un evento de máxima importancia. Incluso se ordenó que se cantaran himnos de "acción de gracias" al Dios católico, como se hacía en ocasiones tales como victorias militares, alumbramientos reales, nombramientos de altos cargos eclesiásticos, etc.

“Por el excelentísimo señor Ministro de Gracia y Justicia en comunicación de 20 del corriente se me dice lo que sigue: «Ministerio de Gracia y Justicia. Subsecretaría. Circular. Habiéndose recibido oficialmente la noticia de la entrada de Su Santidad en Roma, restituyéndose de esta manera con gran consuelo del orbe católico la cabeza visible de la Iglesia a su ordinaria y sagrada residencia, la reina (que Dios guarde) para dar un señalado testimonio de su amor y respeto al Santo Padre, y una prueba más de la religiosidad de los pueblos confiados por la Providencia a su cuidado, ha tenido a bien resolver que a fin de celebrar tan plausible acontecimiento se cante un solemne Te Deum, en todas las iglesias de los dominios españoles» $(. . .)^{18 \prime \prime}$

\subsection{Neutralidad pacífica y armada: 1859-1861}

Dentro del proceso de unificación italiano, el trienio de 1859 a 1861 representa una fase decisiva para las grandes aspiraciones unionistas. No obstante a la muerte de Cavour en junio de 1861, el Reino de Italia agruparía bajo la bandera de la casa de Saboya toda la Península itálica excepto el Véneto y Roma, siendo

que estuvo muy lejos de suceder. Vide Sanddri, V.L., L'intervento militare spagnolo. Rassegna Storica del Risorgimento. Istituto per la storia del Risorgimento italiano, Società nazionale per la storia del Risorgimento italiano. Aquila degli Abruzzi, 1999. Pío IX nombró a España en último lugar en su alocución del 20 de mayo de 1850, a la hora de dar gracias a sus aliados europeos en función de sus méritos. Así, cobra mucha relevancia que dejase a España para el último lugar como muestra de su escasa, o relativa cuanto menos, importancia en su intervención militar.

17. Archivo de la Catedral de Calahorra (ACC), Actas del Cabildo (AC), 174, 16 de diciembre de 1848. Acciones como esta se repitieron en enero de 1849. Vide ACC, AC, 174, 5 de enero de 1849.

18. ACC, AC, 174, 20 de abril de 1850. 
ésta última el único resquicio de lo que un día fueron los Estados Pontificios. Ante esta situación, los príncipes depuestos protestaran por la agresión y pedirán ayuda a Europa: una de las primeras protestas fue la de al Santa Sede ${ }^{19}$.

Pío IX, mediante sus Encíclicas y Alocuciones, se dirigió a todo el episcopado católico comunicándole su angustia y preocupación por las vicisitudes políticas que la unificación italiana podía traer. Del mismo modo, avisaba de su firmeza a la hora de resistir pues desde su punto de vista no se trataba de defender sus intereses personales, sino de garantizar su independencia y los derechos y propiedades de la Santa Sede ${ }^{20}$. Las directrices pontificias Ilegaban a las diócesis por medio de oficios, bien a través de la nunciatura, bien a través de la comunicación entre arzobispados y obispados. Ahora bien, al común de los fieles les eran transmitidas a través de boletines eclesiásticos o en actos relacionados con el culto, ya que durante estos años no era anormal que se hicieran en todas las misas, cantadas o no, oraciones específicas por el Papa "si al cabildo le parecía que interín permanezca en tal estado, tanto en las misas cantadas cuanto en las rezadas que se celebren en esta iglesia, se digan las oraciones juro Papa con su correspondiente secreta y postcomunio, siempre que las rúbricas lo permitan" ${ }^{\prime 21}$.

Cuestión que se puede probar como nos muestra la correspondencia entre Luis Napoleón y Pío IX, en donde el francés aconsejaba renunciar a las provincias perdidas como único medio de finalizar la revolución en Italia, mientras que Pío IX se negaba a hacerlo para no "violar los solemnes juramentos que Nos ligan" y para no "debilitar los derechos, no sólo de los príncipes de Italia que han sido injustamente despojados de sus dominios, sino también de todos los príncipes del universo cristiano, que no podrían ver con indiferencia la introducción de ciertos principios muy perniciosos", ya que se recogía en la Encíclica de 19 de enero de 1860, y a su vez se plasmó en el Boletín Eclesiástico del Arzobispado de Burgos ${ }^{22}$.

19. El 21 de marzo de 1859, la Rusia zarista propuso reunir en un Congreso a las cinco grandes potencias europeas para tratar sobre el problema italiano. Será en el tratado de Zurich donde se prepare el congreso que debería celebrarse en París, si la guerra franco-piamontesa contra Austria no hubiera estallado. Vide Cabeza Sánchez-Albornoz, S., "La actitud de los obispos españoles ante la unificación italiana", Cuadernos de Historia Contemporánea, n ${ }^{\circ} 18$, Universidad Complutense, Madrid, 1996, pp. 45-66.

20. En la Alocución del 22 de enero de 1855 el Papa ya había protestado por la actuación del Piamonte de Víctor Manuel, pero es tras 1859, cuando la unificación de Italia se convierte en el eje principal de muchos de sus escritos. Vide Alocuciones de 21 de junio y 26 de septiembre de 1859; 13 de julio, 28 de septiembre y 17 de diciembre de 1860; 18 de marzo y 30 de septiembre de 1861 y 9 de junio de 1862. Encíclicas de 18 de junio de 1859 y 19 de enero de 1860. Cartas Apostólicas de 26 de marzo de 1860 y 10 de agosto de 1863.

21. ACC, AC, 176, 5 de noviembre de 1859.

22. Párrafo de la carta de Pío IX a Napoleón, publicada en el periódico francés Le Monitor y recogido en la Encíclica de 19 de enero de 1860. Boletín Eclesiástico del Arzobispado de Burgos, (BEAB), T. III, 1860, p. 55. 
Como la diócesis de Calahorra- La Calzada, se inscribía dentro del arzobispado de Burgos, era frecuente que muchas de sus acciones relativas a la cuestión italiana estuvieran alentadas desde Burgos, es decir, desde una administración eclesial inmediatamente superior, lo cual completaba el trasvase informativo entre el papado, el arzobispado, la diócesis y la parroquia:

“El señor chantre manifestó que por una comunicación que había recibido del Excelentísimo e Ilustrísimo señor arzobispo de Burgos, se le decía lo conveniente que sería el que se dirigiesen exposiciones en el sentido de que se lleva hecho mérito por los prelados y cabildos, por exigirlo así el estado angustioso en que se halla el Sumo Pontífice, y habiendo manifestado dicho señor chantre el deseo de saber la resolución del cabildo en esta parte para dar su contestación al referido señor arzobispo de Burgos: se acordó: que se le podía decir que por lo que respecta al cabildo está dispuesto en todo tiempo a hacer cuanto sea necesario y se pueda en obsequio de nuestro santísimo Papa Pío Nono, para mitigar sus amarguras y por el bien de las necesidades de la Iglesia"23.

Otro de los modos por los que circulaba la información de lo que acontecía en Italia, y por el que se iba conformando la opinión pública, era por medio de la prensa nacional de la época. Esta prensa, de origen y ascendencia liberal, reflejaba en sus páginas los sucesos diplomáticos, políticos y militares más importantes de España, Europa y del mundo, además de plasmar información aparecida en otros periódicos tanto españoles como europeos. Estudiando las publicaciones más potentes de la España decimonónica, y teniendo como "punto medio" uno de los ejemplos más representativos y conocidos de este tipo de prensa, La Correspondencia, que pese a no estar vinculado al catolicismo como en el caso de los boletines eclesiásticos, era literalmente pro-gubernamental, nuestra visión de la España del XIX, frente a la unidad italiana en este caso, es mucho más completa ${ }^{24}$.

En lo relativo a la posición del gobierno español frente a la unidad de Italia, es evidente que la prudencia y la diplomacia eran quienes guiaban los pasos de la Unión Liberal, partido que estuvo en el gobierno desde 1858 hasta la revolución de 1868 en alternancia con el partido Moderado. Tras la experiencia ambigua, por sus resultados, de intervenir con tropas como en 1849, se hizo evidente que ni España ni Isabel II querían defraudar a Pío IX, pero que tampoco se iban a enfrentar frontalmente a los unionistas italianos.

23. ACC, AC, 176, 7 de abril de 1860.

24. Por ejemplo, tenemos los diarios progresistas de La lbería y La llustración, quienes apoyaban totalmente los cambios italianos, frente a la prensa neocatólica de El Pensamiento Español, La Regeneración y La Esperanza, quienes atacaron en todo momento el resurgir unionista de Italia. En un discutible término medio localizamos la prensa más aliada con la Unión Liberal, partido creado por O’Donnell en 1854 y que estuvo en el poder durante 1858-1868, como La Época y La Correspondencia, quienes intentaban mediar entre ambas posturas antagonistas desde las filas del moderantismo. 
Ya desde los primeros movimientos del año de 1859, el gobierno español comunicó a sus representantes en las principales Cortes europeas instrucciones tajantes sobre el conflicto de Italia. Afirmando que no tenía derechos que sostener ni obligaciones que cumplir con Italia, el gobierno de la monarquía mostraba su nulo interés por participar en la lucha que se iba a emprender entre potencias extranjeras. Así, la política española pasaría en tiempos de paz por la neutralidad pacífica, y durante los tiempos de guerra por una neutralidad armada ${ }^{25}$.

Así, la "política italiana" de España, mantuvo en todo momento una abierta y distinguida simpatía por la causa de Pío IX y por la de los borbones depuestos, que finalmente sería el final del reinado de esta dinastía en Italia, pero siempre que ello no supusiera romper con el deber nacional y con la prudencia ${ }^{26}$. Tres eran los presupuestos que hubieran movido al gobierno de O'Donnell a intervenir en Italia de forma más directa y beligerante: que la independencia de España se viese en peligro, que peligrase la integridad territorial de la nación o la defensa del honor español ${ }^{27}$.

Esta política que defendía a los Borbones en Italia y al Papa pero que se negaba a claudicar ante los envites de los sectores ultracatólicos y conservadores de España, quienes abogaban por influir directamente en los asuntos itálicos, también fue recogida por la prensa italiana. Sobretodo tras las disputas por los archivos napolitanos, se hizo evidente que la tensión entre Italia y España estaba en aumento, y que sólo una política de "neutralidad armada" podía calmar los ánimos en ambos lugares. Así, hubo testimonios de la prensa italiana que precisaban que "Nosotros no confundimos el gobierno español con la generosa nación" ${ }^{\prime 28}$, mientras que otros, más duros con España, sentenciaban tajantes que "Cada pueblo tiene el gobierno que se merece", siguiendo la máxima aristotélica ${ }^{29}$.

\subsubsection{La Iglesia española ante la invasión de los Estados Pontificios}

La complicada situación del Papa ante los acontecimientos revolucionarios que tenían lugar en Italia, colocaron a Pío IX y al episcopado español en abierta disconformidad con la invasión piamontesa. Además de mantenerse firmes en

25. Becker, J., Historia de las relaciones exteriores...

26. Jiménez Núñez, F., Los Gobiernos de Isabel II...

27. Diario de Sesiones de Cortes (DSC), Leg. 1860-1861. 25 de octubre de 1860.

28. La Perseveranza, 17 de noviembre de 1861, Jiménez Núñez, F., Los Gobiernos de Isabel II..., p. 101. La misma información se puede encontrar en Archivo Histórico Nacional (AHN). Sección de Estado. L. 8070.

29. La Gazzeta di Torino, 22 de septiembre de 1861, Jiménez Núñez, F., Los Gobiernos de Isabel II..., p. 101. La misma información se puede encontrar en AHN. Sección de Estado. L. 8070. 
la defensa de la causa, los derechos, la doctrina de Dios y de su Iglesia, protestaban por los males morales que estos hechos extendían a otras regiones, y contra las agresiones realizadas a religiosos y propiedades del clero italiano. Para el clero católico español: "la causa del Papa es la causa de la Iglesia católica, porque no hay catolicismo sin unidad, ni unidad de sociedad y cuerpo visible sin un gefe (sic) y una cabeza visible ${ }^{\prime \prime 30}$.

En general, su actuación se reduce a cartas de consuelo y firme adhesión a la causa terrenal y territorial, así como a la persona, de Pío IX. Al mismo tiempo, este apoyo se traducía y manifestaba radicalmente contrario a las corrientes ideológicas que favorecieron la revolución ${ }^{31}$.

Por otra parte, otras de las líneas de actuación del catolicismo español serán las exposiciones dirigidas a la reina, Isabel II, bien suplicándole que en nombre del clero y pueblo español enviase palabras de consuelo a Pío IX, bien pidiéndole que hiciera gestiones diplomáticas favorables a la causa del catolicismo. Porque para la Iglesia española, una nación católica como España, no podía permanecer impasible ante tales sucesos ${ }^{32}$.

Finalmente, otros escritos que nutren nuestro estudio son las cartas pastorales dirigidas al bajo clero y a todos los fieles españoles. Es en estos documentos, en donde se informa y reprueban los sucesos italianos y sus tristes efectos para Pío IX. En estas pastorales los obispos además de ensalzar la figura de Pío IX, ponían de relieve la firmeza y tesón del Papa para resistir en su empeño, su satisfacción por la lealtad y fidelidad del clero y del pueblo español, así como se advertía de los peligros y crímenes que la revolución podría llevar a otras naciones de Europa ${ }^{33}$.

"No hay razón, justicia, ni motivo para despojar al Sumo Pontífice de la soberanía sobre las ciudades y provincias que fueron el pequeño territorio de San Pedro; protestemos que no reconocemos en ningún rey, príncipe ni emperador de por sí, ni en todos ellos reunidos en Congreso, derecho, poder o facultad para

30. Boletín Eclesiástico del Arzobispado de Zaragoza (BEAZ), T. II, 1861, p. 89. Carta circular del arzobispo de Zaragoza a los señores curas sobre el papado. Zaragoza, 22 de marzo de 1861

31. Boletín Eclesiástico del Arzobispado de Pamplona, (BEAP), T. VII, 1870, p. 293, en donde se incluye la exposición del obispo de Lérida del 17 de julio de 1859; BEAB, T. III, 1860, pp. 65-67, en donde se recoge la "Exposición elevada (...) a Su Santidad con motivo de los actuales sucesos de Italia"; ACC, AC, 176, 23 de agosto de 1862. Escrito de adhesión al Papa.

32. BEAB, T. III, 1860, pp. 65-67, "Exposición elevada (...) a Su Majestad la Reina Nuestra Señora, con motivo de los actuales sucesos de Italia"; BEAZ, T. I, 1860, pp. 67-69, "Exposición elevada a Su Majestad por los Prelados de la provincia Eclesiástica de Zaragoza con motivo de las turbulencias de Italia y de la grave aflicción de (...) Pío IX".

33. BEAP, T. VII, 1870, p. 293, "Pastoral del arzobispo de Zaragoza". Zaragoza, 10 de enero de 1860; BEAP, T. V, 1861, pp. 153-159. "Carta Pastoral del Obispo de Mondoñedo". Mondoñedo, 24 de abril de 1861; BEAP, T. I, 1863-1864, pp. 89-103. "Pastoral del obispo de Pamplona". Pamplona, 29 de septiembre de 1863. 
desmembrar o tocar en lo más mínimo a los referidos Estados de la Iglesia, o sea del catolicismo con sus doscientos millones de fieles cristianos de todas las naciones: protestemos y digamos muy alto que el despojar a la Iglesia de su patrimonio es, según doctrina católica, un atentado sacrílego y herejía manifiesta" ${ }^{\prime 34}$.

Además, como ya dijimos anteriormente, también estos medios de comunicación eclesiásticos servían como una forma de disponer rogativas públicas de cara a implorar a Dios se terminasen los problemas de su Iglesia, de la misma forma que valían para solicitar limosnas voluntarias y suscripciones al empréstito pontificio, como un medio de socorrer las necesidades materiales y terrenales de la Santa Sede ${ }^{35}$.

No deja de ser expresivo, que en el mismo correo en el que se remiten a la diócesis de Calahorra-La Calzada los ejemplares impresos para suscribirse al empréstito pontificio, hallemos la siguiente información:

“(...) excitando su celo para hacer en obsequio de nuestro santísimo padre Pío Nono cuanto le sea dable, en medio de las angustias que le afligen y que cada día se hacen más impotentes, a causa de los tristísimos acontecimientos que todos conocen, sin que alcancen a remediarlos las voluntarias obligaciones por generosas y abundantes que sean" ${ }^{\prime 36}$.

Por último, también se utilizaban estas pastorales como medio propagandístico de las ideas políticas del catolicismo de esos momentos. Así, como medida reaccionaria frente a la propaganda liberal y revolucionaria de la época, se pedía al párroco, sacerdote o cura, que:

“(...) prevenga (a los feligreses) cuidadosamente contra las maquinaciones del error, que se disfraza con el trage (sic) de libertades políticas, de derechos del hombre, de progresos del siglo, de emancipación de la humanidad, de resurrección de nacionalidades, etc., para derribar el Papado y socabar (sic) los cimientos de nuestra fe $\mathrm{fe}^{\prime \prime 37}$.

34. BEAP, T. VII, 1870, pp. 298-299. "Pastoral del obispo de Lérida". 18 de noviembre de 1859.

35. ACC, AC, 176. Los acuerdos de los días 5, 16, 19 y 24 de mayo de 1860, son los que reflejan el inicio del empréstito.

36. ACC, AC, 176, 16 de junio de 1860. Los distintos boletines eclesiásticos servirán, entre otras cosas, para reflejar y publicitar quienes eran los donantes o suscriptores así como la cantidad que donaban o por la que se suscribían. Como norma general, los obispos y la alta jerarquía eclesiástica eran quienes encabezaban estas listas y quienes entregaban más recursos económicos; algo lógico si tenemos en cuenta que eran quienes más tenían. Basten algunos ejemplos de distintos boletines para probar que se trata de una medida nacional administrada de forma regional: Boletín Eclesiástico del Obispado de Astorga, (BEOA), 10 de enero de 1861; Boletín Eclesiástico del Obispado de Sigüenza, (BEOS), 9 de septiembre de 1861; Boletín Eclesiástico del Obispado de Segovia, (BEOSE), 3 de enero de 1867; Boletín Eclesiástico del Obispado de Osma, (BEOO), 10 de enero de 1867.

37. BEAZ, T. II, 1861, p. 91. "Carta circular a los Señores Curas sobre el Papado". Zaragoza, 22 de mayo de 1861 . 


\subsection{Hacia el reconocimiento del reino de Italia: 1861-1865}

En febrero de 1861 se reunía el primer Parlamento Nacional italiano, que el 14 de marzo de dicho año aprobó la proposición de proclamar a Víctor Manuel del Piamonte: "Rey de Italia por la gracia de Dios y la voluntad nacional". Al reconocer casi toda Europa el nuevo reino de Italia, se estaba reconociendo al mismo tiempo las anexiones efectuadas por el Piamonte entre 1859 y 1860, así como el desmembramiento de los Estados Pontificios.

Este reconocimiento, que precisamente es el que se conmemora en Italia a lo largo del presente año de 2011, causó la natural alarma en la Santa Sede. En junio de 1862 Pío IX y los obispos católicos, reunidos en asamblea, manifestaron su disconformidad y oposición al nuevo reino. Pero la condena no se quedaba sólo ahí, sino que en un intento férreo por instalar un pensamiento unidireccional en las filas del catolicismo, se condenó también algún sector del clero italiano, que rechazando las advertencias de la Iglesia, había fundado algunas sociedades como Clerico liberali, Di mutuo soccorso, o Emancipatrice del Clero italiano.

En lo que respecta a España, mientras que progresistas y demócratas querían que el Gobierno reconociese la nueva realidad italiana, la Corona, las fuerzas moderadas y unionistas no lo admitieron. Es más, de haber actuado en algún sentido lo hubieran hecho del lado de Francia y Austria y en defensa de Pío IX, como en $1849^{38}$.

De este modo y mientras que el gobierno y la monarquía española se negaban a reconocer el reino de Italia, la oposición liberal e incluso los miembros más progresistas del partido unionista español, acusaron al gobierno de usar políticas reaccionarias. Mucho más radicales y duros eran las críticas de los neocatólicos y del clero español en su mayoría, quienes consideraban que el gobierno español no había hecho casi nada a la hora de defender la causa del catolicismo. Así, estos sectores son los que continuarán presionando a Isabel II para que no reconociera el reino de Italia y siguiera apoyando al Santo Padre, y los que hasta agosto de 1865 tengan más apoyos gubernativos y monárquicos.

Tras varios cambios de gobierno entre 1863-1865, en donde gobernaron la Unión Liberal y el partido moderado, se seguía manteniendo la neutralidad y la no aceptación del reino de Italia. Sin embargo, paulatinamente los distintos gobiernos se fueron abriendo a la política europea y comenzaron a plantear a la Corona que tal vez fuera necesario reconocer el reino de Italia, siempre que se garantizase la soberanía de Pío IX sobre Roma ${ }^{39}$.

38. Vide nota 19.

39. Sobretodo tras el gobierno de Miraflores de 1863 y sobremanera tras el gobierno de Narváez de 1864, casi todas las fuerzas políticas españolas, a excepción de los neocatólicos, se comenzarán a mostrar favorables al reconocimiento del reino de Italia. La causa del cambio hay 
Llegados al año de 1865, y viendo que España no necesitaba tantos cambios de gobierno, sino un gobierno, será el mismo Presidente quien le exponga a la reina la necesidad del reconocimiento. Una cuestión poco fácil para Isabel II, quien tenía que atender a las necesidades de O’Donnell, una vez más repuesto en el poder, de Pío IX, por quien sentía una veneración ciega, así como corresponder frente a las presiones de su camarilla, de Austria y de la Santa Sede. Será en junio de 1865, cuando el gabinete de O’Donnell comunique a las Cortes que "cree llegado el tiempo de adoptar un partido respecto a la llamada cuestión de Italia", dejando claro que la cuestión "se resolverá sin lastimar los intereses del catolicismo, que el gobierno respeta y respetará siempre, pues los Ministros de una Reina y de una Nación Católica deben ser y son verdaderos católicos" ${ }^{\prime \prime 4}$.

Este anuncio de cambio de la política exterior española frente al reconocimiento del reino de Italia, no preocupaba excesivamente a la Santa Sede, ya que:

“(...) contaba, para intentar evitar el reconocimiento, de una parte con ciertos medios de presión a utilizar, como el propio clero español y el círculo que rodeaba a la reina, y de otra porque sabía que seguía necesitando de la ayuda del gobierno de la reina Isabel para el futuro de Roma y la conservación del poder temporal del papado" ${ }^{41}$.

Sin embargo, y a pesar de la moderación y templanza de la Santa Sede y de Pío IX ante el cambio de actitud en el gobierno de España frente a la cuestión italiana, los elementos más conservadores de España iniciaron una fuerte oposición en las Cortes y en la prensa, así como la propia Iglesia española, que a través de los periódicos neocatólicos y diversos escritos eclesiásticos, intentaron movilizar a los católicos españoles para impedir que se produjese la tan temida aceptación de la Monarquía italiana ${ }^{42}$. Con tales actitudes, cobra sentido el dicho español de "ser más papista que el Papa".

La prensa neo y ultracatólica, no sólo recogía en sus páginas las intervenciones de los parlamentarios conservadores, sino que tenía su propia campaña

que buscarla en el convenio de 15 de septiembre de 1864, entre Napoleón III y el rey Víctor Manuel, por el que los franceses se comprometían a retirar sus tropas de los Estados Pontificios y el rey italiano prometía preservar el poder temporal del Pontífice.

40. DSC, Leg. 1864-1865. 22 de junio de 1865. Discurso del General O’Donnell.

41. Jiménez Núñez, F., Los Gobiernos de Isabel II...

42. Los periódicos neocatólicos El Pensamiento Español, La Regeneración y La Esperanza, hicieron su propia campaña contra el reconocimiento del reino de Italia, y usaron sus páginas para difundir intervenciones contrarias a tal reconocimiento, y exposiciones que el episcopado español dirigió a la Reina que para resistiera a otras presiones ante la cuestión italiana. Los dos primeros eran claros portavoces del neocatolicismo mientras que el último tenía una fuerte inspiración carlista y ultracatólica. Vide Enríquez, E., La cuestión romana en el diario madrileño El Pensamiento Español de 1870, Madrid, 1987. 
para no permitir que se reconociera el reino de Italia. El Pensamiento Español, fue el encargado de abrir fuego el 4 de julio de 1865 al afirmar que "sería ingrato y ruin el que se llevase a efecto el reconocimiento del reino de Italia y una

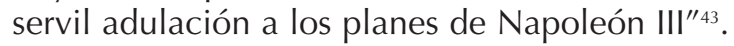

Incluso La Regeneración, en su afán por desestabilizar el gobierno que pretendía reconocer el reino de Italia, llegó a propagar rumores como si fueran noticias, dando ejemplos de cómo actuaban algunos de los políticos y religiosos más importantes de la época. El 12 de julio de 1865 decía lo siguiente: "El rumor de la dimisión del Sr. Mon como embajador de España en París se debe a que éste no quería arrojar su reputación de hombre decente por una ventana al seguir representando a este gobierno". En la misma "cita", también se alarmaba a los lectores con la noticia de que monseñor Claret, uno de los religiosos españoles más influyentes del siglo XIX, pensaba dimitir de su cargo palatino si se materializaba el reconocimiento, así como recogía en sus páginas que el deseo de sor Patrocinio, famosa e influyente mística española conocida popularmente como "la Monja de las Llagas", de abandonar España, era forzado por el gobierno ${ }^{44}$.

Una vez se acercaba la fecha del reconocimiento siguieron recogiendo en sus páginas más ataques contra el gobierno, dando muestras de las protestas que ese hecho estaba produciendo entre los fieles católicos españoles. De nuevo, los ataques que se plasmaban eran tan curiosos como poco probados, pues no pasaban de la mera especulación y creencia en su sentido aristotélico. Así, La Regeneración decía que uno de los convecinos del tarraconense pueblo de Albiol le envía una carta con firmas, manifestando lo siguiente: "En mi nombre y en el de todos los vecinos de Albiol, protesto contra el reconocimiento del reino de Italia" 45 .

En lo referente a las actuaciones de los obispados, vemos como también será frecuente durante esta época dirigir exposiciones a la Corona para que no permita el reconocimiento:

"Siendo público el que todos los prelados y los más de los cabildos catedrales y aún parroquiales han elevado a S.M., representaciones sobre la cuestión del reconocimiento del reino de Italia, y constando al mismo que el señor gobernador eclesiástico sede vacante de esta diócesis, como también el cabildo de la Calzada estaban en representar, le parecía que este cabildo no debía aparecer

43. El Pensamiento Español, no 1.386, 4 de julio de 1865, s/n, p. 3.

44. La Regeneración. 12 de julio de 1865, s/n, p. 2.

45. La Regeneración. 18 de julio de 1865, s/n, p. 2. Si bien es cierto que se recogieron firmas para protestar contra el reconocimiento del reino de Italia, no se aportan datos que demostraran que era todo el pueblo quien firmara. Por otro lado, cabe suponer y plantearse si ante el clima de crispación levantado, los vecinos que estuvieran a favor se hubiesen manifestado públicamente. 
como excepcional presentándose omiso, tanto más en el estado actual de la diócesis sin prelado" ${ }^{\prime \prime 4}$.

Esta misma campaña contraria al reconocimiento de Italia, y por ende, contraria al proceso de unidad nacional italiano, dio lugar a otra campaña a favor del mismo y en defensa de la política exterior del gobierno español. El Contemporáneo, órgano del partido moderado, definía la medida como necesaria. La prensa ministerial, como el Diario Español y La Época, lanzaban informaciones en defensa de un hecho consumado que tildaban de imparable y fundamental para España. En cuanto a la prensa progresista, con La Iberia a la cabeza, lo apoyaban aunque manifestaban su descontento ante una medida tardía y que no iba a tener los mismos efectos para el país que en 1861. Por último, la prensa de cuño democrático y republicano, recibían con los brazos abiertos la medida por su tradicional simpatía con la causa italiana, aunque se mostraban escépticos frente a un gobierno y una monarquía, que no creían debían sostener por más tiempo.

Como conclusión, sólo nos resta decir que ni la recogida de firmas, ni los artículos neocatólicos, ni las condenas lanzadas desde el púlpito, lograron apartar al nuevo gobierno de O’Donnell en su firme resolución de instalar en España la modernidad política de Europa posterior al Congreso de Viena. En cambio, sí que consiguieron movilizar y agitar a la opinión pública española, bien a favor, bien en contra del reconocimiento del reino de Italia.

Aunque el clero español, en su conjunto, estuvo en contra de la unificación y del posterior reconocimiento por parte de España, no todas sus actitudes y ataques son equiparables. Así, no es lo mismo la opinión del obispo de Salamanca cuando manifestó que el reconocimiento iba en detrimento de los intereses católicos ${ }^{47}$, como la opinión del obispo de Osma que calificaba de antiespañol dicho reconocimiento ${ }^{48}$, o la del obispo de Tarazona cuando sentenció que el reconocer el reino de Italia era lo mismo que dar lo santo a los perros y echar perlas a los puercos, pues reconocer el reino de Italia era un deshonor para la reina y para el trono ${ }^{49}$. De entre las filas de los más fanáticos, Ilegaban sermones de algunos curas integristas como el caso de la iglesia del Santo Ángel de Sevilla, en donde "El párroco (...) lanzó desde el púlpito una proclama revolucionaria. Parece que el tema de su sermón (...) fue la cuestión del reconocimiento del reino de Italia; tema que expuso y desenvolvió repitiendo las palabras del Sr. Obispo de Tarazona y la de los furibundos periódicos neocatólicos. Llegaría a Ilamar

46. ACC, AC, 177, 22 de julio de 1865. Escrito del cabildo ante el reconocimiento del reino de Italia.

47. El Contemporáneo. 18 de julio de 1865, nº 1.405, p.1.

48. El Pensamiento Español. 13 de julio de 1865, s/n, p. 3.

49. Vide nota 48. 
impíos, herejes y enemigos de Dios y réprobos condenados al fuego eterno, para los que se muestren partidarios del reconocimiento" ${ }^{\prime 50}$.

\section{El debate entre el progresismo y el catolicismo: Sagasta y el Cardenal Arzobispo de Santiago}

La problemática situación de los Estados Pontificios, y en especial la cuestión de Roma que no se terminaría de resolver hasta 1870 con la toma y capitalidad de "la ciudad eterna" para el recién creado reino de Italia, fueron los asuntos exteriores que más afectaron la sensibilidad de un país de tradición católica como España. Un país en el que aún no se había olvidado el papel ultrarreaccionario de la Iglesia durante los levantamientos carlistas, sobretodo el primero que fue el que estalló con más fuerza y virulencia, ni tampoco, por el otro lado, se había perdonado la actitud anticlerical, y a veces visceral, de algunos liberales en la misma contienda. Aunque la situación en la segunda mitad del siglo XIX no era la misma, lo cierto es que todavía quedaban asuntos por resolver y las desconfianzas y reservas entre adversarios político-religiosos eran evidentes tanto en el Congreso como en la prensa, y en la calle en última instancia ${ }^{51}$.

Fijando nuestra atención y nuestro análisis en las fuerzas que más trabajaron desde España en pos del reconocimiento del reino de Italia, no sólo completamos la visión global que se tuvo desde la nación hispana, por un lado, sino que ponemos encima de la mesa las posiciones más avanzadas y que solían ser motivo de disputa contra quienes defendían el status quo surgido del Congreso de Viena y de la Europa de los Congresos, por otro. Progresistas y demócratas, se esforzaron desde sus foros en exponer su defensa de la unidad de Italia, que en su opinión, no sin fundamento, obligaba taxativamente a la desaparición del poder temporal del pontífice. Así, además de utilizar argumentos de indudable implicación y contenido político también usaban argumentaciones muy próximas a la teología a la hora de presentarlo como una solución beneficiosa para la propia Iglesia. Este mecanismo lejos de ser insólito, se acomodaba a su tiempo histórico, pues como demostramos anteriormente, "las fuerzas partidarias del poder temporal emplean argumentos parecidos" ${ }^{\prime 25}$.

Al retornar la Unión Liberal al poder en 1865, O’Donnell se decidió a tomar partido entre las dos grandes corrientes de pensamiento, la liberal y la

50. El Contemporáneo. 21 de julio de 1865, nº 1.408, p. 2.

51. Vide Montero, F. "La relación Iglesia-Sociedad de la segunda mitad del siglo XIX" en Revista de Historia Contemporánea, no 3, 1984, pp. 87-98; Pérez Garzón, J. S. "La revolución burguesa en España: los inicios de un debate científico. 1966-1979", en Historiografía española contemporánea, X Coloquio de Pau, Madrid, 1980, pp. 91-139.

52. Vide Nota 13. 
reaccionaria, inclinándose a abandonar, y con él la nación bajo su gobierno, la postura más conservadora y reconocer el reino de Italia. La Santa Sede, como no podía ser menos, se plegó a la inevitable, sin que pudiera obtenerse de la Corte de Florencia ningún compromiso o garantía de respeto hacia el poder temporal de Pío IX y de sus sucesores: con el reconocimiento sólo se obtuvo la devolución de los bienes patrimoniales de los Borbones "italianos" destronados. El reinado de Isabel II terminaría así con un reconocimiento forzoso y forzado, imposición de una realidad europea y nacional invulnerable a dogmas del pasado y por ende inexorable para los nostálgicos del Antiguo Régimen, y con el descalabro definitivo de la política moderada acerca de la cuestión italiana.

Las relaciones, pese al reconocimiento de 1865, de ambas monarquías no fueron tan amistosas como cabe suponer tras el reconocimiento: el aperturismo español frente a Italia llegó con varios años de retraso y casi de manera anacrónica, una situación que mejoraría sustancialmente bajo el gobierno provisional surgido de la revolución de 1868 . Así lo demuestran las candidaturas del duque de Génova y del duque de Aosta al trono de España. Más todavía, la elección y nombramiento de Amadeo de Saboya, quien a la sazón era segundo hijo de Víctor Manuel II, tiene lugar pocos meses después del episodio que pondría punto final a la empresa de la unidad de Italia, conocido como el caso de la Porta Pía ${ }^{53}$. Tanto había cambiado España, al menos su gobierno, que pese a que este previsible final tras la decisión de Francia de retirar su defensa militar de Roma, lo cual significaba al mismo tiempo el punto final de la desaparición del poder secular del papado, que las relaciones diplomáticas del reino de Italia con él de España no iban a sufrir el menor menoscabo: no pasaría lo mismo, refiriéndonos al reino de España, en sus relaciones con la Santa Sede y con la Iglesia española ${ }^{54}$.

Más que la rotunda negativa a la unidad de Italia, fue la defensa del poder temporal del papa el argumento central de las exposiciones de la jerarquía eclesiástica española, y así lo había transmitido la prensa ligada a la Iglesia a través de sus medios propagandísticos que ayudaban a configurar el pensamiento de la opinión pública. Esta cuestión tuvo inmediatamente una dura respuesta

53. Por esta puerta que al mismo tiempo era parte de las murallas de Roma, fue por donde entraron los primeros soldados "unionistas" tras haber abierto una brecha con el fuego y metraIla de la artillería.

54. Eiras Roel, A. "La unificación italiana y la diplomacia europea" en Revista de Estudios Políticos, Centro de Estudios Políticos y Constitucionales, n 133, 1964, pp. 129-156. Para hacernos una idea mucho más general sobre el tema Vide Fernández García, A. "El conflicto IglesiaEstado en la Revolución de 1868", en Estudios Históricos. Homenaje a los Profesores José M $^{a}$ Jover Zamora y Vicente Palacio Artad, Departamento de Historia contemporánea, Universidad complutense, Madrid, 1990, T. II, pp. 441-508. 
por parte de algunos periódicos liberales: El Contemporáneo, La Soberanía Nacional, o La Iberia, serán los más tenaces, aunque no podemos descartar otras visiones bastante más moderadas como las de La Correspondencia, pues si bien la naturaleza de este periódico no era la emisión de valoraciones políticas, contribuyó mucho a la conformación de la opinión pública española por la especial atención que prestaba en sus páginas a los debates políticos y periodísticos del momento ${ }^{55}$.

Pese a todas las oposiciones y campañas neocatólicas contrarias al reconocimiento, el gobierno terminó por aceptar el 1 de agosto de 1865 el reino de Italia, lo que lejos de alejar, o por lo menos disminuir, la tensión dentro del episcopado español frente a las políticas estadistas españolas, dio inicio a una amplia polémica entre los partidarios de la defensar del poder temporal de la Iglesia y sus detractores. Será en este punto en el que nos vamos a centrar de la mano del líder progresista riojano Práxedes Mateo Sagasta, en una esquina, y del cardenal arzobispo de Santiago en la contraria.

\subsection{La cuestión del poder temporal de la Iglesia}

Del mismo modo que los periódicos católicos, sobretodo en sus vertientes más conservadoras e integristas conocidas como los neocatólicos, levantaron una campaña contra la unidad de Italia y en defensa del poder secular de la

55. Los estudios sobre la materia reflejan casi con total unanimidad que La Correspondencia si bien tenía una naturaleza conservadora, y por ende no revolucionaria, tampoco puede encuadrarse en la prensa reaccionaria y ultracatólica. La idea común que subyace de los estudios sobra la prensa decimonónica, y por la cual inferimos el planteamiento de este trabajo, es que se trataba de un diario de relativa imparcialidad informativa y con una clara tendencia periodística por significarse como un noticiero simple y Ilanamente. Vide Sánchez Aranda, J. J. y Barrera, C. Historia del periodismo español desde sus orígenes hasta 1975, Pamplona, EUNSA, 1992, pp. 154-157. Por completar en todo lo posible esta nota, cabe destacar que no sólo era el periódico más seguido para el gran público, sino que también alcanzaba la fabulosa cifra de 50.000 ejemplares de tirada y se destacaba por ser pionero en el sistema de venta callejero, claro antecedente de los actuales puestos de prensa o kioscos de prensa. Vide Seoane, M.C. Historia del periodismo en España, Madrid, Alianza Editorial, 1983, t. II, p. 268. Por otro lado, la dedicación de espacio periodístico, dentro de La Correspondencia, a la cuestión italiana es notable como puede comprobarse en algunos de sus números. A saber: La Correspondencia, $\mathrm{n}^{\circ} 858,16$ de enero de 1861, p. 3; $\mathrm{n}^{\circ} 861,19$ de enero de 1861, p. 2; $\mathrm{n}^{\circ}$ 871, 30 de enero de 1861 , p. $2 ; n^{\circ} 880,8$ de febrero de 1861 , p. $2 ; n^{\circ} 885,13$ de febrero de 1861, p. $3 ; n^{\circ} 887,15$ de febrero de 1861, pp. 2-3; n 906, 7 de marzo de 1861, p. 3; n 911, 12 de marzo de 1861, p. 3 ; $n^{\circ} 934,5$ de abril de 1861, p. 1; n 937, 8 de abril de 1861, p. $2 ; n^{\circ} 937,8$ de abril de 1861, p. 2; n 950, 21 de abril de 1861, p. 2; n 960, 1 de mayo de 1861, pp. 3-4; $n^{\circ} 962,3$ de mayo de 1861, p. 2; n 975, 16 de mayo de 1861, p. 3; $n^{\circ} 976,17$ de mayo de 1861, p. 2; $n^{\circ}$ 982, 23 de mayo de 1861, p. 2; no 1.002, 13 de junio de 1861, pp. 2-3; no 2.591, 21 de junio de 1865, p. 2; $n^{\circ} 2.592,22$ de junio de 1865, pp. 1-3; $n^{\circ} 2.593,23$ de junio de 1865, p. 1; $n^{\circ}$ 2.595, 25 de junio de 1865, p.1. 
Iglesia, por su parte el periodismo progresista mantuvo principalmente un auténtico duelo con los diarios "neos" La Esperanza y La Regeneración, intentado por todos los medios intelectuales a su alcance desmontar los argumentos y tesis que éstos presentaban ante la opinión pública española, en la que se defendía el poder temporal del papa como un elemento imprescindible para la Iglesia así como una cuestión dogmática de fe. Así parece bastante claro que lejos de existir una posición nacional, y sobretodo popular y pública por ser más precisos, clara, existían dos grandes corrientes de pensamiento sobre este tema ${ }^{56}$.

Ya desde 1860, una década antes de la conquista de Roma y cinco años antes de que España reconociera el reino de Italia, decía La Iberia:

"Los periódicos que quieren hacer de dogma la soberanía temporal del Papa llevan su celo por los intereses del rey de Roma hasta un punto absurdo, lo demuestra suficientemente la actitud del gobierno de los cardenales enfrente del Piamonte. Pues qué, ¿en qué momento de poner la fuerza a la fuerza, no hace aquél una completa división entre ambos poderes, el espiritual y el temporal? ¿Qué dogma es ese, qué verdad eterna, que para prolongar su fugaz existencia algunos días ha tenido que buscar instrumentos materiales de fuerza?"57.

También en esas mismas fechas, un demócrata republicano como Emilio Castelar publicaba una serie de artículos en los diarios La Discusión y La Iberia, sobre el poder temporal del papado, los cuales llegaron a ser muy relevantes y conocidos para la opinión pública española ${ }^{58}$, no obstante además de político era doctor en Filosofía, en donde manifestaba en una carta abierta a la Iglesia, que la mejor forma para salir del conflicto era la salida de Pío IX de Roma:

"El Papa no puede continuar en Roma sin ser esclavo de las grandes Potencias y sin contribuir eficazmente a la esclavitud de Italia. El Papa no puede salir de Roma para vivir en el cautiverio y ser un instrumento político. El Papa en Roma impide la unidad de Italia. Mientras Roma no ascienda al trono de Italia, la unidad nacional no se consumará; y mientras la unidad nacional no se consume, el gran país tendrá esa ardorosa fiebre que asalta a todos los artistas

56. Jiménez Núñez, F. "Actitud de las fuerzas políticas españolas, demócratas y progresistas, frente al movimiento de unidad de Italia, en el periodo de 1859-1868", en Revista de Estudios Políticos, $\mathrm{n}^{\circ}$ 64, 1989, pp. 259-280. También es interesante el estudio de Eiras Roel, E. El partido demócrata español (1849-1868), Pamplona, Rialp, 1961.

57. La Iberia, 16 de septiembre de 1860, ${ }^{\circ} 1.889$, p. 2. Insistiendo en este mismo punto, en el mismo artículo se dice que la prensa católica está confundida sobre qué era lo temporal y qué era lo espiritual "Ilevados por la tradición católica de nuestro país (...) (y por) seguir una obediencia ciega al Pontificado".

58. Vide Nota 54. 
empeñados en una gran obra; la fiebre creadora, que en los pueblos se Ilama fiebre revolucionaria" ${ }^{\prime 59}$.

Con la llegada del año de 1865 y más concretamente tras el 1 de agosto y el reconocimiento oficial de la unificación italiana por parte del gobierno unionista de O’Donnell, no deja de ser paradójico y anecdótico la coincidencia entre el proceso de unidad italiano y el nombre del partido en el poder, la Unión Liberal, volvieron a resurgir, pero ahora con más violencia, las discusiones sobre el "poder temporal" y la "cuestión de Roma". Frente a los ataques conservadores a O’Donnell por, según la visión conservadora, haber secundado la política progresista y con ello haber abandonado a Pío IX en un momento tan crítico, Castelar saldrá al paso diciendo:

“Todos los reaccionarios pintan la suerte de Pío IX para probar que la revolución es un monstruo de ingratitud; no comprenden que la libertad no es un poder, sino un derecho. (...) La "cuestión romana» no está fuera de la dinámica que ha impulsado el proceso unificador, el derecho de la lucha de los pueblos frente a sus soberanos, independientemente de que en este caso sea además de Rey, Papa" ${ }^{\prime 60}$.

Sin embargo a estas actuaciones, contrarias o favorables a la actuación del rey Víctor Manuel II y de su gobierno, lo cierto es que el monarca italiano terminaría por apoderarse de Roma, único territorio que había quedado bajo el poder de la Iglesia en 1870 e independiente del resto de Italia, para hacer de ella la capital de su reino y culminar así el proceso de unificación territorial italiano. Mientras la ciudad de Roma estuvo protegida por el gobierno francés de Napoleón III, a través de una guarnición militar, la conservación y tranquilidad de los Estados Pontificios y de la soberanía temporal del papa quedaban garantizadas. Del mismo modo, los compromisos acordados entre los gobiernos italiano y francés debían ir por el mismo camino, no obstante en septiembre de 1867 los acuerdos franco-italianos fueron violados y "algunas hordas impulsadas por manos ocultas, se echaron sobre el territorio pontificio con la perversa intención de sorprender y ocupar Roma" ${ }^{\prime 61}$, por lo que de nuevo tropas francesas volvieron a Roma de cara a ayudar a Pío IX hasta que la contienda franco-prusiana obligó a Napoleón III a retirarlas: la derrota francesa de 1870 fue la chispa que hizo que el reino italiano de Víctor Manuel II enviase un

59. La Discusión, no 1.477 y La Iberia, $n^{\circ} 1.914,16$ de octubre de 1860; “El poder temporal del Papa", segundo artículo de una serie de tres.

60. La Democracia, 10 de julio de 1865, Jiménez Núñez, F., Los Gobiernos de Isabel II...

61. "Protesta del gobierno pontificio contra la usurpación de los Estados de la Santa Sede". Vaticano, 20 de septiembre de 1870, en BEAB, t. XII-XIII, 1869-1870, p. 212. También en ACC, AC, 177, 2 de noviembre de 1867 y en ACC, AC, 177, 14 de diciembre de 1867, se da cuenta a nivel de la diócesis riojana de los hechos que tuvieron lugar a finales de 1867 en Roma y se hacen rogativas por el bienestar político y personal de Pío IX. 
ejército de ocupación a la que hasta entonces había sido la capital política y religiosa del catolicismo. En septiembre de ese mismo año y tras la toma de Roma se completaba la unificación territorial italiana ${ }^{62}$.

\subsubsection{Sagasta en la tribuna}

Práxedes Mariano Mateo-Sagasta y Escolar ${ }^{63}$, parlamentario liberal de la rama progresista, docente y director del periódico La Iberia, es junto a Castelar una de las voces políticas e intelectuales españolas que más trabajaron por la aprobación de la unidad de Italia ${ }^{64}$. Como correlativo lógico en la defensa de la cuestión italiana, también fue uno de los personajes que más atacó el poder temporal del papado, todo lo cual le llevó a pronunciar sonados discursos parlamentarios y a escribir distintos artículos publicados en La lberia, que le hicieron rivalizar tanto con parlamentarios moderados de la época, sobretodo con aquellos procedentes de las filas del partido en el gobierno, la Unión Liberal, como con la alta jerarquía eclesiástica ${ }^{65}$.

Sin entrar a analizar cual era el estilo oratorio de Sagasta, destacamos la notable cualificación retórica-argumentativa y también la inmensa fuerza que se desprenden de sus palabras así como la aceptación que éstas tuvieron entre sus correligionarios, una cuestión que, suponemos, llevaría consigo más de un quebradero de cabeza para sus adversarios a la hora de rebatirle. He aquí cómo caracteriza su oratoria un contemporáneo suyo, Francisco Cañamaque:

“No es Sagasta un orador erudito, metafísico, profundamente ilustrado; es un orador oportuno, enérgico, incisivo, de lógica contundente, de palabra bastante

62. No así su articulación. Vide García Sanz, F. "Dossier, la unificación italiana: Fare l'Italia" en La Aventura de la historia, Madrid, $n^{\circ}$ 34, 2001, pp. 56-61. Resulta especialmente indicativo el inicio del artículo: "La mera agregación de las piezas del rompecabezas italiano bastaba para cambiar los mapas, pero no para consolidar una nación que tenía que redefinir su identidad (...) (redefinir) los retos del nuevo estado". Parece claro que aunque fueron muchas las fuerzas que contribuyeron al proceso de unidad italiano, las perspectivas de Garibaldi nunca fueron las mismas que las de Cavour, ni las de este idénticas a las de Manzzini, ni las de los monárquicos frente a los republicanos, ni las de los unitarios en comparación a las de los federalistas, pese a que se terminó por englobar a todo bajo el concepto del Risorgimento.

63. Vide Ollero de la Torre, A., "Sagasta y su proyecto político", en Berceo, Instituto de Estudios Riojanos, Logroño, 1983, n 104, pp. 83-102. Además del contenido de la obra en sí mismo, es relevante consultar la bibliografía para conocer los primeros estudios efectuados sobre el personaje.

64. Para conocer de forma profusa la personalidad política de Sagasta, contamos con el estudio de Ollero Vallés, J.L., El progresismo como proyecto político en el reinado de Isabel II: Práxedes Mateo-Sagasta, 1854-1868. Instituto de Estudios Riojanos, Logroño, 1999.

65. Para saber más acerca de la técnica retórica de Sagasta contamos con el estudio de Caballero López, J. A., (editor), Retórica e historia en el siglo XIX. Sagasta: oratoria y opinión pública. Instituto de Estudios Riojanos, Logroño, 2008. 
correcta y fácil, de giros y prontos tribunicios, de apóstrofes magníficos, de ironías mortales, de exposición clara, de verdadera elocuencia política. Su talento es más práctico que teórico; su naturaleza de lucha más que de paz. No ilustra cuando habla; pero enardece, entusiasma, agrada. Hiere el sentimiento y llama la risa, toca al corazón y produce regocijo" ${ }^{\prime \prime 6}$.

En su rol de parlamentario Sagasta trató de debatir y zanjar la posición española frente al emergente reino de Italia en el corazón político de la España liberal, el parlamento, al menos en nueve ocasiones desde diciembre de 1860 y hasta marzo de $1861^{67}$. Tras las infructuosas tentativas del gobierno de la Unión Liberal por eludir el tema italiano, cuyas razones ya quedaron explicadas anteriormente, lo cierto es que Sagasta iba agotando su paciencia al mismo tiempo en que hacía acopio de voluntad, tesón y empeño, para discutir desde la minoría parlamentaria progresista sobre el posicionamiento estatal y gubernativo de España ante los hechos que ocurrían en la península itálica:

“(...) yo suplico al señor Ministro que se sirva, si lo tiene por conveniente, señalar el día en que se ha de entrar en el debate tanto tiempo esperado de la cuestión de Italia, si es que no quiere que en el mismo momento se entre en ella. (...) Dos meses hace que tuve el honor de anunciar mi interpelación, y unas veces por enfermedad del Sr. Ministro, que hemos lamentado siempre, y otras con pretextos frívolos, porque si hubiera sido siempre por la enfermedad de S.S., nada más hubiéramos dicho (...) entre otras consideraciones, por la de que no podía asistir el Sr. Ministro de Estado, que (es) el más interesado en defender la política del Gobierno en la cuestión de Italia"68.

Una vez que en la sesión de 6 de marzo de 1861 se comenzó a tratar el tema de los asuntos italianos, Sagasta tuvo el honor de "iniciar este importante

66. Cañamaque, F., Los oradores de 1869, Madrid, 1879, p. 276. En esta misma obra hayamos en la página 2645 una interesante comparación del estilo retórico sagastino frente a otros grandes oradores de su tiempo: "Se me dirá que carece de las formas de Castelar, de la corrección de Martos, de la abundancia de Cánovas. Pero tiene fuego, electricidad, mucha electricidad en su palabra y en su persona".

67. Aunque el tema de la unidad de Italia se trató en trece sesiones con Sagasta como protagonista, después de su creación y hasta 1865 se trataría el tema del reconocimiento, o no, del reino de Italia. Consideramos seis como las más relevantes tanto por su composición y extensión, como por el motivo y finalidad de nuestro estudio ya mencionado en la introducción. En las restantes sesiones tan sólo hayamos breves alusiones hacia el tema e intentos infructuosos de abrir el debate parlamentario al respecto. Las que hemos usado, fundamentalmente, son las siguientes: DSC, leg. 1860-1861, nº 59, 15 de diciembre de 1860, pp. 891-897; $\mathrm{n}^{\circ}$ 87, 4 de febrero de 1861, p. 1.433; $\mathrm{n}^{\circ}$ 98, 20 de febrero de 1861, p. 1624; $\mathrm{n}^{\circ} 110,6$ de marzo de 1861,

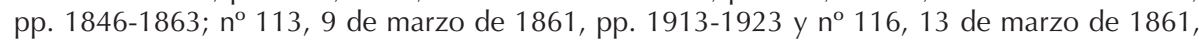
pp. 1972-1973. Vide www.unirioja.es/fundacionsagasta.

68. DSC, leg. 1860-1861, nº 98, 20 de febrero de 1861, p. 1.624. 
debate para dirigir graves cargos al Gobierno por la conducta política que ha seguido en las negociaciones diplomáticas relativamente a la cuestión de Italia" ${ }^{\prime \prime 9}$. Tras las primeras exhortaciones, encontramos la primera crítica mordaz frente a la "moderada" política exterior tildándola como "arrastrada por mezquinas pasiones y bastardos intereses personales", y considerándola, desde las filas del progresismo liberal, como "una política personal, (...) una política desfavorable a nuestro sistema de Gobierno, (...) una política en oposición a nuestra historia y contraria a nuestro porvenir" ${ }^{\prime \prime 7}$.

Tras este punto, un Sagasta insaciable por su naturaleza y porque había esperado bastante tiempo para interpelar al gobierno, comenzaba a disparar toda su línea argumentativa e ideológica contra el poder temporal de los pontífices, ya que esta era una de las barreras políticas que habían de derribar los partidarios de la revolución y posterior unificación italiana, frente a las férreas posiciones de la Iglesia, de Isabel II y de la Unión Liberal:

"(...) si el poder temporal de los Papas nada tiene que ver con el espiritual; si en vez de ser dogmático es herético, pasaremos sin embargo por esta herejía en cambio del bien que puede reportar al pontificado, o de los beneficios que pueden alcanzar todos los que a este poder temporal están sometidos? (sic). Pocas palabras bastarán para probar que el poder temporal de los Papas, lejos de ser beneficioso y útil al pontificado, es perjudicial, y que en vez de alcanzar algunas ventajas los países sometidos a este poder temporal, están condenados a la esterilidad y a la muerte" ${ }^{\prime \prime 7}$.

Siguiendo con el desarrollo de la intervención parlamentaria, a la par que daba muestras de una óptima preparación católica en lo referente a la historia y a los mitos de la propia Iglesia ${ }^{72}$, comenzaba Sagasta a resumir certeramente los mojones pasados del pontificado católico hasta llegar a su época contemporánea, dentro de la cual opinaba no tenía sentido el poder temporal de Pío IX puesto que la inmovilidad dogmática del catolicismo era contraria a la "movediza" política liberal, "en la que todo cambia, se modifica y altera" en una

69. DSC, leg. 1860-1861, no 110, 6 de marzo de 1861, pp. 1846-1853.

70. Vide Nota 69.

71. Vide Nota 69.

72. Resulta adecuado resaltar que fuentes religiosas como la Biblia, en primer lugar, y otros textos de su misma idiosincrasia e índole, en los cuales bebió Sagasta, son de carácter teológico, ahistórico y pre-científico, si bien también aluden y reflejan algunos hechos y aspectos históricos en sus páginas a tener en cuenta. Hasta fines del siglo XVIII, y como norma general, los Evangelios se leían en la convicción de veracidad total. No es hasta principios del siglo XIX cuando llegaron pensadores racionalistas a examinar estos escritos prescindiendo e incluso negando toda dimensión sobrenatural, si bien a lo largo de la historia del catolicismo han surgido distintas corrientes teológicas heterodoxas que no sintonizaban, plena o sencillamente, con la posición oficial y hermética de la jerarquía eclesiástica. 
argumentación que recuerda mucho al antiguo filósofo griego Heráclito y su famoso "panta rei" traducido como "todo fluye":

"Que el poder temporal es más perjudicial que útil al poder espiritual del pontifica-
do, nos lo dice a gritos la historia. El pontificado sin el poder temporal alcanza el
trono de los Césares, salvó la civilización de las tempestades del Norte, detuvo la
marcha triunfal del carro del bárbaro Alarico, salvo la ciudad eterna del feroz Atila,
(...) mientras que con su poder temporal no ha sido más que el juguete constante
de ambiciosos soberanos. Restablecido unas veces en este poder por bayonetas
extranjeras (...) pasó de Federico II, de Felipe el Hermoso, de Carlos V, de Luis XIV,
de Napoleón I, (...) cohibido por los poderes de la tierra, en vez de ser por él domi-
nados, y envuelto en el triste espectáculo del proclamas excitando a la pelea, de
trofeos de guerra, de pueblos saqueados por los que se llaman sus defensores, de
ruinas y de sangre; ¿y todo por qué?... Por conservar un pedazo de tierra"73.

Para finalizar su extensa intervención del día 6 de marzo en el congreso de los diputados, unas de las más ricas en relación a sus contenidos, Sagasta realizaría un vaticinio político abierto pero certero a modo de previsión futura de corto plazo, que el tiempo y los hombres, la historia en síntesis, se encargarían de hacer realidad. Y es que, en un ejercicio de excelente capacidad analítica e intelectual, fruto de su preparación cultural y político-profesional, llegó a indicar cuales eran las alternativas que le restaban al pontificado si aceptaba, o no, las tesis progresistas, y cuales serían sus consecuencias y resultados:

"El poder temporal de los Papas es contrario al catolicismo, es perjudicial al pontificado, y es matador para todos los pueblos a él sometidos; pero se dice: si la unidad de Italia ha de tener lugar, ¿qué va a ser del pontificado? (...) Si el Papa, confiando la mucha fuerza moral que todavía conserva, transige franca y generosamente con el que ya es hoy Rey de Italia, (...) entonces el Papa podrá ejercer el pontificado en Roma, en Roma, dividida por el Tíber en dos ciudades distintas; en Roma donde existe la ciudad religiosa y la ciudad imperial; en una puede estar el Jefe de la Iglesia, y en la otra el Jefe del Estado. Pero si el Papa no se aviene a una transacción, si continua encerrado en la inflexible fórmula de non pussumus; si el Papa ha de tener el poder temporal, siquiera sea en el punto de su residencia, entonces, señores, el Papa no puede residir en Roma (...) sin ser esclavo de grandes potencias y sin contribuir a la esclavitud de la Italia. ¿Tiene guarnición extranjera? Pues será por ella encadenado, y Roma no será de los italianos, y se levantará como un obstáculo insuperable a la unidad de Italia. ¿No tiene guarnición extranjera? Pues los italianos se levantarán para arrojar el trono del Rey de Roma y colocar al suyo en el Quirinal"74.

73. Vide Nota 69.

74. Vide Nota 69. Lógicamente nos referimos a un vaticinio centrado en los condicionantes de su tiempo, la segunda mitad del siglo XIX, en la cuestión relativa al reino de Italia y la conquista de Roma. 
En la misma línea del demócrata republicano Emilio Castelar, con quien mantenía ciertas similitudes de pensamiento las cuales se acentuaban mucho en el trasunto del poder temporal de Pío IX y de sus sucesores en el cargo, como hemos podido comprobar a lo largo de este estudio, la última solución que acuñaba el progresismo de la mano de Sagasta era el traslado de la silla de San Pedro hasta la bíblica ciudad de Jerusalén: "En Jerusalén es donde puede residir el Papa, si ha de vivir redimido de toda esclavitud; porque contra Jerusalén no hay las rivalidades que contra Roma"75.

Como es de suponer, las palabras pronunciadas por el político riojano causaron un gran revuelo en el parlamento. Máxime, si consideramos que la mayor parte del mismo se componía de políticos moderados salidos de las filas de la Unión Liberal. Así, tras escuchar las réplicas del partido que ejercía el gobierno en España, y en una nueva sesión, la del 9 de marzo de 1861, Sagasta continuaba afilando su lengua que a modo de espada progresista, iba abriendo camino en la carne de sus rivales causando toda la sangría posible si se me permite la metáfora pseudobelicista. Ante las insinuaciones y acusaciones más o menos claras y directas a su anticatolicismo, Sagasta no sólo se defendía de ellas sino que en la misma intervención, además, respondía con la misma moneda: poniendo en tela de juicio el liberalismo y catolicismo de sus opositores gracias a su preparada contraargumentación y a una más que digna rapidez intelectual, y todo ello, ante los aplausos que le granjeaban desde las tribunas afines. Tal era su potente y provocativa, en sentido positivo, capacidad retórica y oratoria:

"Pero luego decía el Sr. Mena: los tratados de 1815 no se han opuesto a la independencia y libertad de los pueblos; eso habrá sido cosa de la Santa Alianza. ¿Y qué es la Santa Alianza más que una consecuencia de los tratados? ¿Qué es la Santa Alianza de que nos ha hablado S.S. al hablar de la libertad sagrada? ¿Qué es la Santa Alianza sino la reunión de tres Príncipes, uno católico, otro cismático y otro hereje? ¡Vaya una alianza para la libertad de los pueblos! (Aplausos en las tribunas). ¡Vaya una alianza a la que apela S.S. para defender el catolicismo de que se ha mostrado partidario, pero del cual no lo será nunca más que yo! (...) Los que defienden eso no quieren la unidad ni la libertad ni la independencia de los pueblos; no quieren la unidad, la libertad y la independencia de la iglesia" ${ }^{\prime \prime 6}$.

Por último, Sagasta en la sesión del 13 de marzo de 1861, pocos días antes de que se creara oficialmente el reino de Italia, hacía un último esfuerzo, tan necesario para el liberalismo como estéril a tenor de la débil, por tenue, política que siguió usando la Unión Liberal hasta 1865 en el tema de Italia, para que

75. Para conocer el origen de las palabras de Castelar Vide Nota 58. Para localizar las de Sagasta Vide Nota 69.

76. DSC, leg. 1860-1861, nº 113, 9 de marzo de 1861, pp. 1913-1916. 
España entrase de pleno en la modernidad continental y occidental ${ }^{77}$. Con esta última intervención, no sólo estaba demostrando la estrecha relación que guardaba un asunto exterior, la unidad de Italia, con el interior, la articulación del reinado de Isabel II bajo el signo del moderantismo, sino que mostraba su faceta más cristalina y no partidista como político liberal:

\begin{abstract}
“(...) El señor Romero Ortiz en su discurso no ha hecho más que fotografiar la unión liberal: querer y no querer hacer una cosa, y aprobar la contraria. (...) También S.S. me ha supuesto otra equivocación; que yo me había ocupado de la cuestión de Italia mirándolo sólo bajo el punto de vista de los intereses de aquel país. (...) Pero además hay otra razón, y es la conveniencia que resulta para España, la conveniencia que resulta para el sistema representativo que aquí tenemos, la de procurar el planteamiento de este sistema allí donde no exista, y la de fortificarle donde se encuentre establecido" ${ }^{\prime 7}$.
\end{abstract}

\title{
4.1.2. Sagasta contra García Cuesta
}

Cerrando la parte de Sagasta como parlamentario, pasaremos ahora a ver cuáles eran las posturas del Sagasta articulista. Si bien sus posturas no fueron muy diferentes a las anteriores, tan sólo pasaron cuatro años entre sus intervenciones parlamentarias y la redacción de varios artículos publicados en La Iberia, y la posición del gobierno y de la Iglesia siempre fue la misma, lo cierto es que hasta la mitad del año de 1865 España era uno de los pocos países europeos

77. Conviene matizar que cuando afirmamos que las tesis de Sagasta eran positivas para el liberalismo, en abstracto, no nos estamos fijando tanto en sus matices progresistas como en los resultados prácticos que tuvieron las políticas exteriores de la Unión Liberal, para forjar la imagen pública y supranacional de una España ultracatólica y reaccionaria tal y como, por citar un ejemplo concreto, la prensa liberal italiana recogía en sus páginas y comentamos anteriormente en las notas 28 y 29. Del mismo modo, ese apego por una tradición católica, inmutable y absoluta, herencia de tiempos pasados, no iba en consonancia con los cambios necesarios para el funcionamiento interno del régimen liberal español y para su extensión a todas las facetas: políticas, económicas, sociales y culturales. El hecho de que cuatro años más tarde, el mismo partido en el gobierno recapacitase y cambiara la postura estatal y nacional sobre la cuestión italiana, y que en 1868 una gran masa sociopolítica se decidiera quitar a Isabel II del trono, es la mejor prueba de ello.

78. DSC, leg. 1860-1861, n 113, 9 de marzo de 1861, p. 1923. Continuación de la interpelación sobre los asuntos de Italia. Es interesante el estudio de Ollero Vallés, J. L., "Sagasta y el discurso del progresismo sobre la nación española en el siglo XIX" en Caballero López, J. A., Retórica e historia en el siglo XIX. Sagasta: oratoria y opinión pública. Instituto de Estudios Riojanos, Logroño, 2008, pp. 227-250. Por el origen y finalidad de nuestro estudio, destacamos sobretodo la siguiente intervención parlamentaria de Sagasta del día 6 de marzo de 1861, en donde se mostraba partidarios de una unión ibérica de España y Portugal: "porque la revolución de Italia es nuestra revolución; porque los sucesos de Italia son nuestra historia; porque lo que la Italia pretende ser entre el Mediterráneo y el Adriático, es lo que pretendemos nosotros ser entre el Mediterráneo y el Océano". Vide Nota 68. 
que no había reconocido, todavía, el reino de Italia de 1861. Un anacronismo político, imperdonable tanto para progresistas como para ciertos sectores moderados cansados del enroque monárquico y eclesial que ahora comenzarían a hacer aparición, del que no podían separarse temas tan controvertidos como el poder temporal del sumo pontífice. Como contrapartida, ahora nos fijaremos en las manifestaciones y artículos del cardenal arzobispo de Santiago, puesto que junto y contra Sagasta fue uno de los protagonistas más famosos de un debate cruzado a dos bandas.

Empezaremos por mostrar cual era la posición "personal", más bien podríamos decir arzobispal, de Miguel García Cuesta ${ }^{79}$, aunque podemos adelantar sin temor a errar que no aportaban casi ninguna novedad en el campo de las argumentaciones y posicionamientos católicos, que mostramos en la primera parte de nuestro estudio, en relación con la visión que tuvo la Iglesia en general y su alta jerarquía en particular acerca de los cambios habidos en Italia y en la Santa Sede. Si bien, es de justicia que reconozcamos una mayor profundización en sus argumentos en donde, al mismo nivel de Sagasta, hacía referencias a textos sagrados y textos históricos pese a que en ningún momento se matizase dónde terminaba el mito y la instrumentalización política de la Historia y donde empezaba la realidad histórica en sí misma ${ }^{80}$. Para el arzobispo de Santiago el reconocimiento del reino de Italia eran un error tremendo para España, de producirse, pues haría recaer sobre la nación el anatema y la condena papal que Pío IX había dispuesto para los usurpadores de Italia y los expoliadores de sus Estados, además de que el país:

“(...) perdería la hermosa fisionomía que desde Recaredo tiene nuestra Nación, la cual debe sus principales glorias al catolicismo, y que por su catolicismo arrojó de su suelo con porfiada lucha a los bárbaros musulmanes, descubrió y civilizó un nuevo mundo y humilló al famoso capitán del siglo" ${ }^{181}$.

Ante esta actuación, que por otro lado no fue única como ya quedó asenta$\mathrm{do}^{82}$, de nuevo Sagasta saltaba a la palestra, ahora en calidad de director de La Iberia, publicando el 26 de julio de 1865 una exposición dirigida a la reina, en donde advertía a la jefa del Estado sobre el peligro que se cernía sobre las posiciones "neocatólicas" y en contra de las exposiciones que los obispos le habían

79. Para conocer más sobre el personaje Vide García Cortés, C., El Cardenal García Cuesta (1803-1873): un eminente arzobispo compostelano en la España liberal. Santiago de Compostela, Cabildo de la catedral de Santiago, 2006.

80. Vide Nota 71.

81. BEA Santiago (BEAS), T. IV, 12 de julio de 1865, p. 331; “Exposición del Emmo. Sr. Cardenal Arzobispo de esta Diócesis sobre el proyectado reconocimiento del Ilamado reino de Italia".

82. En esta misma línea, Vide Nota 46-50. Desde las diócesis españolas se mandaron durante la primera mitad de la centuria decimonónica distintas exposiciones a la reina Isabel con el objeto de que impidiera el reconocimiento del reino de Italia. 
enviado previamente, en donde se le recomendaba negarse a aceptar el reino de Víctor Manuel II. En todo el artículo, en donde Sagasta no traiciona su estilo ni sus argumentaciones anteriores, combate la potestad temporal de los papas haciendo uso de textos evangélicos y religiosos, y lo que es más sorprendente, lo hizo retando a los obispos para "que la impugnen y digan si es falsa la doctrina espuesta (sic), sin son falsas las citas que hacemos, si no son sacadas del Evangelio y de los Padres" ${ }^{\prime 3}$.

El cardenal arzobispo de Santiago, Miguel García, no sólo aceptaba el reto, el envite que Sagasta había lanzado a todo el episcopado español, en su nombre, sino que además lo hacía como paladín del episcopado, de la Iglesia católica y del propio Pío IX. Así fue como se inició una dura e interesante polémica entre ambos púgiles de la palabra. Por un lado quince fueron las cartas que, basadas en los textos sagrados y en los principios de la filosofía cristiana, dirige el cardenal arzobispo de Santiago al director de La Iberia, en donde el autor da su punto de vista sobre los temas que a lo largo de esos años se estaban debatiendo en prensa y en el parlamento ${ }^{84}$.

Haciendo gala de una buena preparación cultural, además de la teológica que se supone a todo prelado, defenderá el poder temporal del papado de la misma forma en que pondrá de manifiesto todos los errores en los que han caído todos aquellos que negaban la potestad temporal del pontífice. En todas sus epístolas el arzobispo de Santiago copiará al pie de la letra las inculpaciones aparecidas en el periódico progresista contra el poder temporal del papa, y por extensión, contra el episcopado español. Si bien en ningún momento Sagasta ataca al catolicismo, pues es de ley certificar que Sagasta en ningún momento cuestiona la Iglesia como institución, sí que criticaría ferozmente pero con respeto y argumentos más o menos sólidos, las intervenciones de la jerarquía eclesiástica, tanto en global como en particular.

Sintetizando en la medida de lo posible los contenidos de la exposición y artículos de Sagasta, puestos en primer lugar por una mera cuestión cronológica, el punto de inicio no puede dejar de ser más claro: se trata de una crítica a la postura del episcopado español ante el reconocimiento del reino de Italia. Fundamentalmente hará lo mismo que hizo en el parlamento con el gobierno de la Unión Liberal, pero cuatro años más tarde y tomando como objetivo a los

83. La Iberia, $n^{\circ} 3.414,26$ de julio de 1865: "Exposición de Sagasta a la Reina sobre el neocatolicismo".

84. Las cartas fueron publicadas en BEAS, T. IV, 1865. Las cinco primeras fueron, además, reproducidas en La Iberia entre el 28 de septiembre y el 17 de diciembre de 1865, así como se publicaron al año siguiente en una obra titulada Cartas a la Iberia. Vide Calvo Pastor, H., "Las metáforas animalizadoras como recurso retórico en los artículos de fondo de La Iberia, Interlingüística, n 17, 2006, pp. 238-249, y "La imagen del otro en la Iberia de Sagasta: el apelativo como recurso retórico", Retórica e historia en el siglo XIX, 2008, p. 111-162. 
obispos, en vez de a sus antagonistas políticos. En lo referente al aspecto meramente formal, las acusaciones en primer lugar se centran en la ignorancia intracatólica del "obispado español" ya que "la inmensa mayoría no goza más que de una fe de convención, en la que lo divino y lo humano, los dogmas y las opiniones, forman una mezcla confusa, un caos sobre el que se ciernen las más espesas tinieblas" ${ }^{\prime 85}$. Luego, pasará a acometer contra la arrogancia episcopal puesto que "se creen fuertes en los principios religiosos, y a todas horas los encontráis dispuestos a lanzar anatemas, por poco que os desviéis de sus teorías". También denomina como intolerantes y tercos al común de los obispos porque "si oponéis cualquier dificultad a sus sistemas, os mirará como hereje; si decís que en la Iglesia hay que atenerse a lo que siempre fue creído por los apóstoles, os tildará como un innovador peligroso; si le preguntáis la razón de por qué es malo el progreso, la libertad, la civilización, según nos ha dicho el obispo de Tarazona, os llamará libre pensadores". Finalmente, la crítica de Sagasta concluiría afirmando la terquedad, la jactancia, en el sentido de autocomplacencia, la ingratitud y la estupidez de la jerarquía católica, concretamente les llega a llamar mentecatos, por creerse infalibles del mismo modo que creían en la infabilidad del papa, por pensar que la Iglesia se arruinaría sin el poder temporal, y por turbar la paz e intereses de la nación que les financiaba ${ }^{86}$.

Finalmente, Sagasta en la segunda parte de su exposición volverá a oponerse de forma absoluta a la aceptación de la soberanía civil del papado, demostrando cómo ese ejercicio de poder terrenal era contrario al espíritu y a las doctrinas del cristianismo. Basándose en la razón, la autoridad y la "historia", que aparecen aquí como los pilares de su tesis, el director de La Iberia explicaba que el pontífice no podía ser rey y representante al mismo tiempo de una religión que predicaba caridad, humildad y perdón, por cuanto eran inherentes a los reyes el poder, la riqueza y el castigo, tal y como Jesucristo había querido

85. Vide Nota 83. Para no resultar pesados y dificultar la lectura del texto, aclaramos que hasta el final del trabajo todas las citas textuales que se hagan sobre los textos periodísticos de Sagasta que estamos diseccionando, proceden de la misma fuente y puede consultarse a través de esta misma referencia.

86. Sin ánimo de entrar en otro tipo de debate, interesante pero con alta carga subjetiva, que nos aleje del estudio de la Historia, queremos reflejar que algunos autores que han estudiado este mismo caso, Vide Cabeza Sánchez Albornoz, S., Ibid., han creído conveniente tachar en su trabajo de "improperios" las palabras de Sagasta. Nosotros, en un saludable ejercicio de respeto, en la medida de lo posible, frente a sensibilidades religiosas, seglares y laicas, preferimos no tomar partido, aunque entendemos que del mismo modo que haya quien sea de la opinión de que se trata de adjetivos degradantes, también haya quien opine que Sagasta se estaba ajustando a la verdad. Desde aquí respetamos todas las posiciones siempre que se encuadren en un marco efectivo de respeto equitativo y recíproco, pero no esta entre nuestros objetivos directos y claros la creación de una determinada opinión al respecto. 
decir, según los evangelios canónicos, en la famosa frase de "dad al César lo que es del César y a Dios lo que es de Dios" ${ }^{\prime \prime 7}$.

Para dar mayor validez teológica a sus argumentos, Sagasta también se apoyará en las doctrinas de los Santos Padres, quienes, según el líder progresista, habían afirmado a través de sus textos el rechazo a la soberanía civil del papado. Si bien esto no es motivo suficiente para decantar el favor del debate a su posición, demuestra el aperturismo y enorme preparación cultural y teológica del político riojano, la cual se echa en falta, en el sentido contrario, el político, por parte del obispado. Entre las citas de los Santos Padres encontramos referencias a figuras tan representativas del catolicismo primitivo como San Gelasio, el obispo Sinesio, San Gregorio Magno o San Bernardo. Precisamente es de esto último de quien toma y reproduce las palabras que el santo dijo al papa Eugenio II:

"Podéis adquirir de una manera o de otra oro, plata, poder, pero no lo obtendréis por el derecho apostólico, porque San Pedro no ha podido dar lo que él no tenía; lo que él tenía os lo ha transmitido, a saber, el cuidado de la Iglesia" ${ }^{\prime 88}$.

De todo lo expuesto anteriormente, deduce Sagasta que los papas al adquirir a través del paso de la historia el poder temporal en sus propios dominios estatales, y más aún, al ejercerlo durante tantos siglos, habían estado permanentemente en contradicción con los libros sagrados y las doctrinas que allí se contienen. Todo lo cual había contribuido enormemente al descrédito de la Iglesia, así como causado grandes perjuicios al papado y a Italia. Queda notablemente claro que el poder temporal había sido, por lo tanto, el causante de todos los males.

¿Quo vadis Sagasta? Algo muy similar debió pensar García Cuesta cuando leyó las palabras del político y periodista camerano. Utilizando únicamente las tres primeras cartas del cardenal arzobispo de Santiago, que son fundamentalmente las que responden a todas las críticas vertidas por los textos de Sagasta, veremos de qué forma contestaba a las tesis progresistas sobre el poder temporal del papado y otras cuestiones colaterales. La primera, con fecha del 20 de agosto de 1865, a la sazón, diecinueve días después de que España reconociese el reino de Italia, es en donde se rechaza la primera parte de la exposición de Sagasta, poniendo en tela de juicio las acusaciones de ignorancia, arrogancia, obstinación, etc., afirmando que Sagasta confundía arrogancia con una

87. El término "César" se ha usado a menudo, en los países de tradición cristiana, para identificar el poder temporal, en contraposición al poder espiritual, o la esfera civil, en contraposición a la religiosa. Su origen está en el evangelio de San Mateo, 22, 15-21, en respuesta de Jesús a la pregunta farisea de si era lícito pagar impuestos a Roma. Recalcamos la ahistoricidad de este tipo de textos que se mueven entre la realidad histórica y el mito religioso hasta que científicamente se demuestre lo contrario.

88. Vide Nota 83. 
firmeza inquebrantable, la del episcopado, y que los obispos no eran tercos sino tradicionalistas. Quizás lo más sorprendente, además de la iniciativa del arzobispo en sí misma y de la calma que parece envolver a sus templadas palabras, era la aceptación de su intolerancia, pero matizando que respondían a esa categoría porque no podían permitir ni la indiferencia ni la libertad religiosa, ni mucho menos "el error" que se encuentra a medida que el individuo se alejaba del dogma católico. Aún con todo, y quién sabe si como una forma de azuzar el ingenio sagastino sutilmente, le dice que "son tolerantísimos y muy caritativos con los que yerran" ${ }^{\prime \prime}$.

Por otro lado, y siguiendo con el análisis de las cartas arzobispales, no admite en absoluto el calificativo de ingratos, pero sí el hecho de depender económicamente del Estado, ya que fue éste quien le confiscó su patrimonio obligándose por ello al mantenimiento material del culto y del clero, aunque por ello no deja de reconocer que ahora la Iglesia tenía menos poder económico que antes de la concordia entre España y la Santa Sede. En un alarde de erudición política, incluso llega a citar a los estadistas conservadores franceses Barrot y Guizot, para quienes la verdadera historia del papado demostraba la necesidad de unir en una sola persona ambos poderes: el espiritual y el terrenal. Sobre este mismo punto, encontramos en la segunda carta la defensa de las necesidades terrestres de todo sacerdote desde los mismísimos apóstoles, ya que ellos mismos desde los primeros tiempos del cristianismo necesitaron de propiedades "para los gastos comunes de la sociedad que iban a formar en la tierra, y que se habría de componer, no de ángeles, sino de hombres que tienen necesidades terrestres" 1 . De esta forma, el sacerdocio se contemplaba como un "proletario de la religión" por parte del arzobispo, y como trabajador que era, debía tener un sueldo. Tal y como dijo San Pablo y recogía García Cuesta:

"El honorario del sacerdote no es una simple limosna, sino una cosa que se le debe de justicia, como al militar, al cultivador, al pastor; y así puede no sólo recibir, sino reclamar, caso necesario, las cosas que le sean precisas para vivir y llenar su misión: estas son deudas de justicia, deudas sagradas, que no se pueden dejar de cumplir sin dejar de violar los derechos de la equidad y de la religión" ${ }^{\prime \prime 1}$.

En la defensa del poder temporal del papado, García Cuesta se basaba en el hecho mismo de que Jesucristo en ningún momento había condenado tal soberanía. Un argumento de Perogrullo y muy lógico para cualquiera que se haya acercado a leer el nuevo testamento, pues no hayamos nada que incline la

89. BEAS, Tomo IV, 20 de agosto de 1865, p. 398. Primera carta del cardenal arzobispo de una serie de tres.

90. BEAS, Tomo IV, 24 de agosto de 1865, p. 417. Segunda carta del cardenal arzobispo de una serie de tres.

91. Vide Nota 89. 
balanza en uno y otro sentido de forma clara, contundente y directa. Por otro lado, sí reconoce que el mismo Cristo estableció la diferencia entre las dos potestades en la célebre sentencia recogida en el evangelio de San Mateo, "dad al César lo que es del César y a Dios lo que es de Dios"92, aunque lo interpreta de una forma distinta por cuanto para él, la finalidad de ese testimonio era "promover la una la salvación eterna y la otra la felicidad temporal, y que cada una tiene una esfera de acción distinta de la que no debía salirse" ${ }^{\prime \prime 3}$, si bien esa ley general y universal tenía una única excepción para el autor: la soberanía temporal del papa en un pequeño Estado.

Por último y como broche final a nuestro estudio, el cardenal arzobispo justificaba la actitud de los obispos ante el reconocimiento del reino de Italia, porque él mismo acababa de demostrar en sus textos que si los papas tenían derecho a ejercer el poder temporal, la usurpación de los Estados Pontificios eran el mayor atentado ante ese derecho, lo que además ponía en peligro la soberanía espiritual. De este modo, y pese a que el reconocimiento era un hecho, creía que era la obligación de los obispos defender la Iglesia cuando los proyectos políticos pretendían lastimar sus intereses religiosos, de ahí que afirmara:

"Al saber recientemente los obispos españoles que el gobierno proyectaba reconocer el reino de Italia y por consiguiente la usurpación de los Estados Pontificios, hemos expuesto que ese acto sería la aprobación y la sanción del despojo sacrílego del Papa, que envalentonaría a los usurpadores para llevar a cabo su pensamiento de destronarle, y que esto no debía hacerlo la nación católica sin ser cómplice de semejantes atentados, sino abstenerse como se había abstenido hasta aquí, de tal reconocimiento" ${ }^{\prime \prime 4}$.

Con estas palabras, y esperemos que con este trabajo en suma, queda claro el qué movió al clero español a intervenir para impedir el reconocimiento del reino de Italia y de qué modo lo hizo.

\section{Conclusiones}

Este periodo de la historia de España, en el que los generales presiden sus Gobiernos, se caracterizó por una activa política exterior, aunque no siempre fuera la más conveniente a los intereses del país ni a los de sus ciudadanos. Sin embargo, puso en evidencia la presencia española en los foros internacionales y en toda cuestión de ámbito europeo.

92. Vide Nota 86.

93. BEAS, Tomo IV, 30 de agosto de 1865, p. 432. Tercera carta del cardenal arzobispo de una serie de tres.

94. BEAS, Tomo IV, 30 de agosto de 1865, p. 435. Tercera carta del cardenal arzobispo de una serie de tres. 
En lo relativo a la parte interna del gobierno español y teniendo en cuenta que el régimen isabelino se apoyaba en los liberales para pervivir, la neutralidad armada de España cohesionaba al pueblo español y hacía que la gran mayoría no se decantase por opciones ultramontanas y carlistas, o bien, por opciones socialistas, demócratas o republicanas.

Si la actitud del alto clero fue, en su amplía mayoría, contraria al reconocimiento del reino de Italia, la otra parte del mismo, la más numerosa, secundaría, también en su gran mayoría, el proceder de sus jerarquías. En todo caso, las posturas del catolicismo español nunca fueron completamente unánimes tras el reconocimiento, pues se dieron posturas que iban desde el total apoyo al episcopado español, hasta quienes empezaban a aceptar este hecho como un mal menor. Estos prelados, fueron el blanco de duras críticas y censuras por parte de la prensa neocatólica ${ }^{95}$.

La prensa liberal, en general, y la más progresista con La Iberia de Sagasta al frente en particular, se puso de acuerdo a la hora de acusar al clero español, y sobretodo al episcopado, de haber desbordado el asunto y de haberse prestado a las intrigas políticas de los neocatólicos. Algunos periódicos progubernamentales de la época llegaron a dar a entender al gobierno español de 1865 que tenía que elegir entre los católicos o los liberales ${ }^{96}$.

Pese a todas las oposiciones, condenas y campañas contra el reconocimiento del reino de Italia, el 1 de agosto de 1865, el gobierno y la monarquía española lo reconocían. Este hecho, le costó a O’Donnell su cargo, incrementaría las protestas entre el episcopado, y dejaba la senda expedita a nuevos enfrentamientos entre los partidarios del poder temporal del Papa y sus detractores, teniendo la cuestión de Roma como telón de fondo.

Aunque la cuestión italiana no tuvo demasiada repercusión en la prensa española, en el sentido de que se trataba como normal general como un asunto más de los correos extranjeros, la prensa católica no pudo permitir la sumisión del Papa a otro poder temporal, y por eso llenaron sus páginas con este asunto.

Las complejas relaciones exteriores y bilaterales entre España, Italia y la Santa Sede, no eran sino reflejo de las complejas relaciones interiores entre el Estado y la Religión, y viceversa: el conflicto Iglesia-Estado, catolicismo-progresismo, exhibía las limitaciones de muchos hombres de Iglesia en materias filosóficas y políticas, del mismo modo que ponía al descubierto una de las cuestiones más arduas en las construcciones liberales de Italia y de España. En este mismo sentido, en la confrontación Iglesia-Estado en torno al programa políticoreligioso de la Iglesia, se percibe con nitidez y claridad meridiana el arcaísmo de las estructuras sociales y mentales de los grupos opuestos a cualquier viso de

95. El Contemporáneo, no 1.407, 20 de julio de 1865, p. 3.

96. El Diario Español. 12 de julio de 1865, Jiménez Núñez, F., Los Gobiernos de Isabel II... 
cambio, y por otra parte la esterilidad de la moderación como arma política en esas circunstancias.

Algunos periódicos como La Discusión, señalaban que el camino a seguir para evitar esta molesta situación ahora y en el futuro, era apostar por una Iglesia libre en un Estado libre ${ }^{97}$.

97. La Discusión, $\mathrm{n}^{\circ} 2.931,14$ de julio de 1865, p. 2. 